\title{
Review
}

\section{Mass Spectrometry-Based Identification of Muscle-Associated and Muscle-Derived Proteomic Biomarkers of Dystrophinopathies}

\author{
Paul Dowling, Ashling Holland and Kay Ohlendieck* \\ Department of Biology, National University of Ireland, Maynooth, Ireland
}

\begin{abstract}
The optimization of large-scale screening procedures of pathological specimens by genomic, proteomic and metabolic methods has drastically increased the bioanalytical capability for swiftly identifying novel biomarkers of inherited disorders, such as neuromuscular diseases. X-linked muscular dystrophy represents the most frequently inherited muscle disease and is characterized by primary abnormalities in the membrane cytoskeletal protein dystrophin. Mass spectrometry-based proteomics has been widely employed for the systematic analysis of dystrophin-deficient muscle tissues, using patient samples and animal models of dystrophinopathy. Both, gel-based methods and label-free mass spectrometric techniques have been applied in comparative analyses and established a large number of altered proteins that are associated with muscle contraction, energy metabolism, ion homeostasis, cellular signaling, the cytoskeleton, the extracellular matrix and the cellular stress response. Although these new indicators of muscular dystrophy have increased our general understanding of the molecular pathogenesis of dystrophinopathy, their application as new diagnostic or prognostic biomarkers would require the undesirable usage of invasive methodology. Hence, to reduce the need for diagnostic muscle biopsy procedures, more recent efforts have focused on the proteomic screening of suitable body fluids, such as plasma, serum or urine, for the identification of changed concentration levels of muscle-derived peptides, protein fragments or intact proteins. The occurrence of muscular dystrophy-related protein species in biofluids will be extremely helpful for the future development of cost-effective and non-invasive diagnostic procedures. Novel biomarker signatures of dystrophinopathies will be indispensible for the swift evaluation of innovative therapeutic approaches, such as exon skipping, codon-read-through or stem cell therapy.
\end{abstract}

Keywords: Biomarker discovery, Duchenne muscular dystrophy, dystrophin, dystrophinopathy, mass spectrometry, muscle pathology, neuromuscular disease, proteomics, skeletal muscle proteome

\section{INTRODUCTION}

Over the last decade, skeletal muscle proteomics has developed into a new discipline within the field of basic and applied myology [1]. Proteomics has been applied to a wide range of muscle-related topics,

\footnotetext{
${ }^{*}$ Correspondence to: Kay Ohlendieck, Department of Biology, National University of Ireland, Maynooth, Co. Kildare, Ireland. Tel.: +3531708 3842; Fax: +353 1708 3845; E-mail: kay.ohlendieck@ nuim.ie.
}

including muscle development [2], muscle fibre type specification [3, 4], the effects of various physical exercise regimes [5-7], muscle recovery following injury [8], gender dimorphism [9], myokine secretion [10-12], chronic stimulation-induced fast-to-slow muscle transitions [13], muscular hypertrophy [14], unloading-related muscular atrophy $[15,16]$, the effect of chronic hypoxia [17-19] and fibre wasting during the natural process of skeletal muscle aging [20-22]. In addition, proteomics was instrumental 
in the determination of key post-translational modifications in muscle proteins such as glycosylation [23], phosphorylation [24], carbonylation [25], nitrosylation [26] and acetylation [27]. The systematic proteomic screening of skeletal muscle pathologies has included the analysis of patient biopsy material and muscle preparations from established animal models of muscle diseases, covering neuromuscular abnormalities such as drug-related muscle damage [28], toxin-associated muscle alterations [29], denervationinduced muscular atrophy [30, 31], motor neuron diseases [32-34], limb-girdle muscular dystrophy [35], hyper-excitability related myotonia [36], insulin resistance and diabetes-associated muscle weakness [37-39], obesity-related changes in muscle tissues [40, 41], inclusion body myositis [42], autoimmune myasthenia gravis [43], dysferlinopathy [44], myofibrillar myopathies [45-47], and post-mortem changes in skeletal muscle [48]. In addition, the downstream effects of dystrophin deficiency were studied by various proteomic approaches [49].

Building on these extensive sources of information, this review focuses specifically on the mass spectrometry-based identification of novel proteomic biomarkers of dystrophinopathies and their potential as future diagnostic tools. Proteins are listed by functional families including internal muscle-associated proteins involved in the contraction-relaxation cycle, glycolysis, mitochondrial metabolism, cellular signaling, ion handling, the extracellular matrix, the cytoskeleton and the cellular stress response, as well as muscle-derived peptides, protein fragments and intact proteins that are leaked or released into body fluids such as plasma, serum or urine. The importance of proteomic biomarkers for the future development of superior diagnostic procedures is discussed.

\section{PROFILING OF MUSCLE-ASSOCIATED AND MUSCLE-DERIVED PROTEINS}

\section{Skeletal muscle proteomics}

High-resolution gel electrophoresis and/or liquid chromatography have been routinely used to separate various protein constellations from skeletal muscle specimens. The identification of muscle proteins by mass spectrometry has been carried out with both labelling approaches and label-free analyses [50]. The systematic cataloguing of the highly dynamic skeletal muscle proteome has established a list of several thousand proteins and isoforms that are present in greatly varying concentration ranges in voluntary contractile tissues [4, 51-53]. Organelle proteomics has established the subproteome of distinct muscle fractions [54], such as the sarcolemma, the sarcoplasmic reticulum and mitochondria [55-57]. Recently, several extensive reviews have summarised and critically examined the impact of large-scale proteomic approaches for our general understanding of human muscle biology [1], skeletal muscle differentiation and aging [58], muscle plasticity and fibre heterogeneity [59] and exercise-induced fibre adaptations [60, 61], as well as the molecular composition of the contractile apparatus [62] and the dystrophin-glycoprotein complex [63]. In addition, the technical challenges and emerging techniques in muscle proteomics [50] and key issues in proteomic biomarker discovery in the field of neuromuscular disorders [64] have been reviewed. These articles have outlined in detail the most commonly employed methods for protein separation and protein identification used in muscle tissue proteomics and also contain detailed listings of proteomic investigations with relevance to inherited muscle diseases. Thus, for detailed background information on proteomic strategies as specifically applied to skeletal muscle biology, we would like to refer to the above listed publications.

\section{Skeletal muscle proteome complexity}

Various technical limitations and biological issues complicate the proteomic screening of crude muscle extracts for the swift identification of new diseasespecific biomarkers. These issues are encountered during almost all global analyses of protein constellations in complex tissues and organs [65-67]. On the cellular level, skeletal muscles are highly diverse in their composition and consist of the main contractile fibres, which exist in a wide range of multinucleated slow-oxidative, fast-oxidative-glycolytic, fast-glycolytic or hybrid cell types [68], in conjunction with satellite cell pools underneath the basal lamina, distinct layers of connective tissue comprising of the endomysium, perimysium and epimysium, a complex network of capillaries, and motor neurons and their specialized connection sites at the neuromuscular junction [64]. On the subcellular level, various muscle proteins display a multi-compartmental localization and a considerable dynamic in their cellular movements and interaction patterns [54]. On the molecular level, muscle tissues display a highly diverse number of protein families with an exceptionally large variety of isoforms, which exist in a wide dynamic range of expression levels [4, 51-53]. 
Technical limitations and biological issues in muscle proteomics

In the case of technically straightforward cataloguing studies of the muscle proteome [51, 53], the exceptional sensitivity and analytical capability of modern mass spectrometers enables the comprehensive evaluation of heterogeneous tissue extracts for the efficient identification of specific isoforms of even low copy number proteins [69]. In contrast to shotgun proteomics, the extensive molecular and cellular heterogeneity in contractile tissues presents a serious analytical challenge in comparative pathobiochemical studies. Muscle diseases are often related to complex changes. For example, the progressive nature of $\mathrm{X}$-linked muscular dystrophy is associated with alterations in the interstitial volume, a drastic increase in connective tissue, elevated endomysial fat layers and the infiltration of damaged fibres by cells that provide the natural immune response. These additional changes in an already highly heterogeneous cell mixture certainly complicate the interpretation of studies using tissue proteomics. In addition, the preferential susceptibility of certain fibre types to necrosis may result in complex and unpredictable fiber type transitions during different disease stages [70]. A potential preparative artifact is the occurrence of abundant blood-borne proteins in skeletal muscle homogenates, such as hemoglobin subunits, which depends heavily on the appropriate usage of tissue perfusion prior to protein extraction and large-scale protein separation.

These technical problems and biological matters may genuinely complicate the proper interpretation of findings from comparative tissue proteomics and make it difficult to distinguish between protein changes due to general tissue damage, adaptive processes during regeneration cycles and highly disease-specific alterations downstream from the primary genetic insult. In the case of analyzing needle biopsy material from Duchenne patients, an additional issue is the fact that a tissue sample from a single biopsy might not be fully representative of the overall pathology in whole muscle [71]. Usually a wide heterogeneity of muscle defects exists within the neuromuscular system in the same patient, limiting the validity of biomedical data received from a single biopsy. This may seriously complicate the extrapolation of proteomic biomarker findings in the case of monitoring therapeutic interventions.

\section{Serum markers of muscle damage}

In the past, an array of muscle-derived protein markers has been used for diagnostic purposes. However, many of these biomarkers do not exhibit a high degree of specificity and/or consistent concentration changes in the acute or chronic disease stage, which restricts their usefulness for accurate diagnosis, proper monitoring of dystrophic progression and clinical outcome measures. General serum markers of muscle injury or cellular damage include creatine kinase, carbonic anhydrase isoform CA3, troponin subunit TnI, myosin light chain MLC1, fatty acid binding protein FABP3, myoglobin, aspartate amino transferase, alanine amino transferase, hydroxybutyrate dehydrogenase, adenylate kinase, aldolase, pyruvate kinase, enolase and lactate dehydrogenase [64, 72, 73]. The graph in Fig. 1 shows the normal range of human plasma-associated proteins. It has been estimated that the concentration range of plasma proteins ranges from $\rho \mathrm{g} / \mathrm{ml}$-values at the low end to $\mathrm{mg} / \mathrm{ml}$-values at the high end [74]. General markers of tissue leakage, including serum proteins indicative of muscle damage, are marked in Fig. 2. Their elevated appearance in serum or plasma samples is a general sign of impaired fibre integrity. It is important to note that plasma and serum biochemistry depends considerably on the reproducibility of the sampling method, which is especially crucial in the case of comparative studies.

\section{Proteomic complexity of body fluids}

Although plasma, serum, urine, saliva and other biofluids are ideal sources for the swift discovery of new disease markers, as well as present the preferred minimally invasive specimens to test normal individuals, at-risk groups and patients, the potential problem with the wide dynamic protein expression range is a serious analytical issue with most body fluids [75]. This is especially apparent in the case of the serum and plasma proteome and neither liquid chromatography nor high-resolution gel electrophoretic methods are capable of separating the entire spectrum of proteins within a complex biological mixture [76]. The extremely wide dynamic range of protein concentrations present in human plasma, as outlined in Figs. 1 and 2, represents a major obstacle. Low-abundance proteins such as many cytokines are present at a concentration in the $\rho \mathrm{g} / \mathrm{ml}$ range, while albumin is present at concentrations in the region of $30-45 \mathrm{mg} / \mathrm{ml}$ [77]. This huge difference in concentrations represents at least twelve orders of magnitude with the potential to be even greater as some biomolecules are present at concentrations lower than many cytokines [78]. In addition, many low-abundance components bind to highly abundant proteins, such as albumin, 


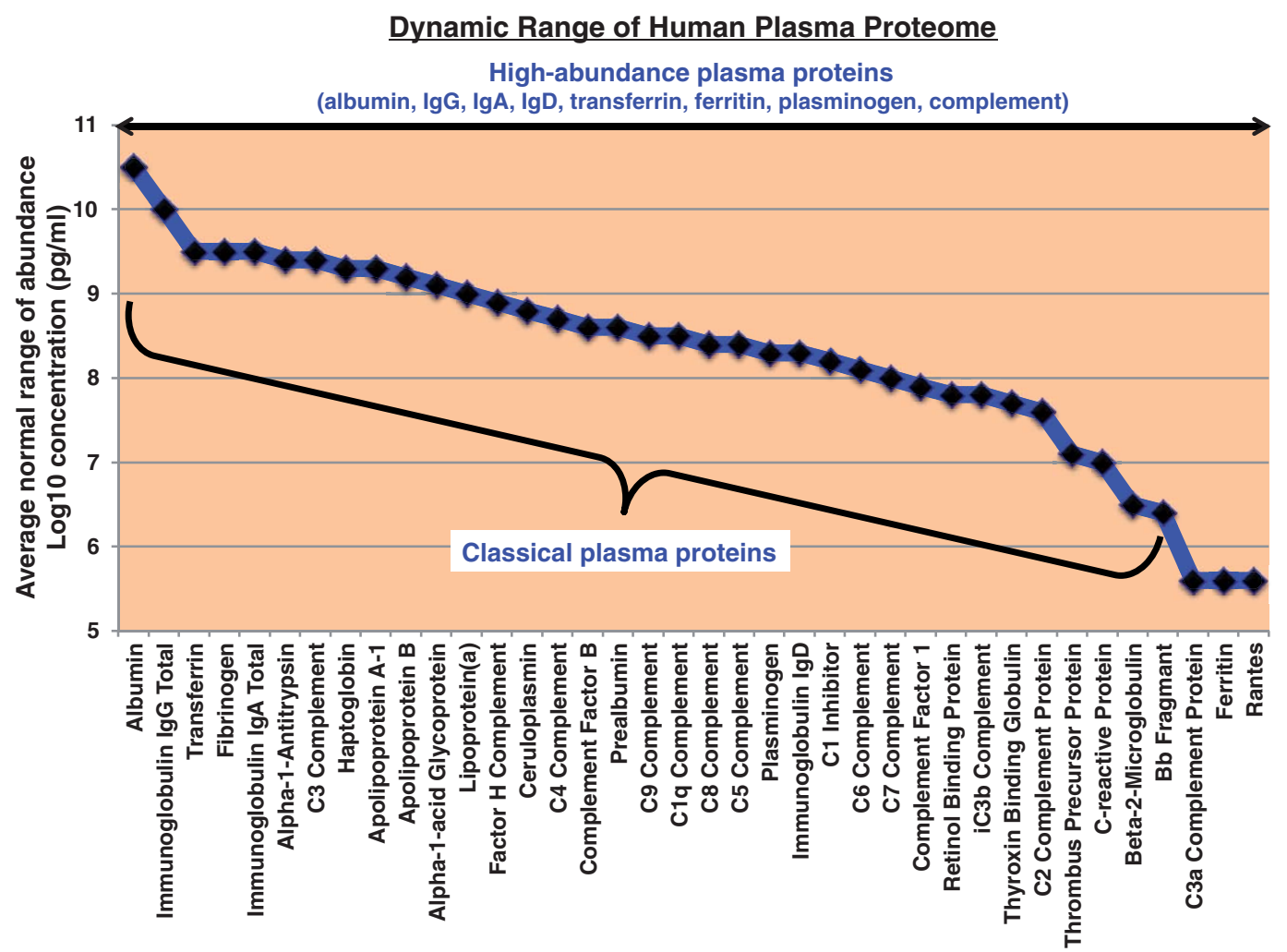

Fig. 1. Graphical presentation of the dynamic range of high-abundance proteins in the human plasma proteome. Shown is the average concentration range of high-abundance plasma proteins representing classical plasma-associated proteins, such as albumin, various immunoglobulins, transferrin, ferritin, plasminogen and numerous complement proteins.

thereby masking their presence. This adds a layer of complexity to their detection and quantification, which should be properly considered when using prefractionation approaches, such as immuno-depletion protocols $[79,80]$.

A major advantage of body fluids is the ability to take serial samples to monitor disease burden or response to therapeutic agents based on altering levels of suitable protein biomarkers. Biological material assayed for biomarker discovery can also originate from proximal fluids, which are defined as biofluids in close or direct contact with the site of disease. In contrast to serum or plasma, it is very likely that these biomarker-rich reservoirs will facilitate the discovery of disease-related biomarkers. Depending on the specific disorder, suitable proximal biofluids may include cerebrospinal fluid, broncho-alveolar lavage fluid, saliva, urine, cerumen, tears and various gastrointestinal fluids such as bile, pancreatic juice and gastric juice [81-83]. For example, levels of HIP/PAPI (hepatocarcinoma-intestine-pancreas/pancreatitisassociated-protein-I) were found to be approximately 1000 -fold higher in pancreatic juice as compared to serum from patients diagnosed with pancreatic adenocarcinoma [84]. However, mirroring difficulties associated with investigating serum or plasma, proximal biofluids also have a wide dynamic range of protein abundance levels, with cerebrospinal fluid having up to twelve orders of magnitude [85]. To help assist the detection of low-abundance and disease-specific biomarkers, a number of fractionation and enrichment strategies are available to provide a standardised method to process biofluid specimens including immuno-depletion, combinatorial hexapeptide ligand libraries and nanoparticle harvesting approaches.

\section{Protein enrichment strategies in biofluid proteomics}

The extremely high concentration of a few proteins in serum or plasma seriously interferes with the identification of low copy number proteins. Therefore the high concentration of proteins such as albumin, transferrin, fibrinogen, haptoglobin, antitrypsin, transthyretin and various immunoglobulins 


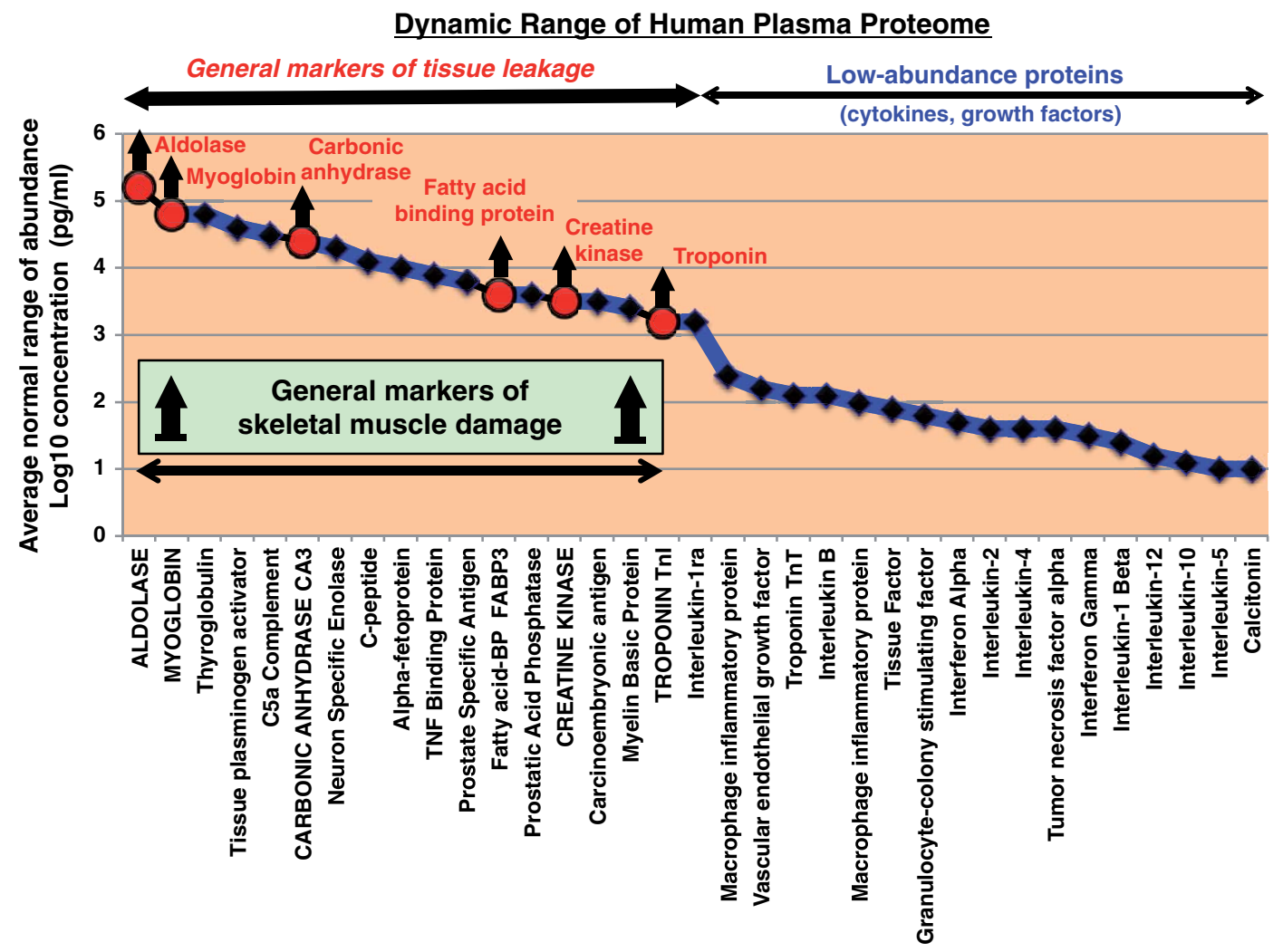

Fig. 2. Graphical presentation of the dynamic range of low-abundance proteins in the human plasma proteome. Shown is the average concentration range of general plasma-associated protein markers of tissue leakage and low-abundance plasma proteins. The average, normal abundance of typical muscle-derived proteins, such as aldolase, myoglobin, carbonic anhydrase, fatty acid binding protein, creatine kinase and troponin subunits, is marked. Drastically increased levels of these proteins in serum or plasma samples are indicative of general muscle damage and disintegration of fibre integrity.

necessitates often pre-fractionation steps in order to be able to detect low-abundance proteins in serum samples [79, 80, 86]. Immuno-depletion of biofluid specimens for the removal of highly abundant proteins is a practical and reproducible solution. Typically, selected proteins are removed using immuno-depletion columns containing antibodies against the hyperabundant proteins such as albumin, IgG, IgA, IgM, fibrinogen, transferrin and haptoglobin. Removal of high-abundance proteins and consequently the establishment of an enriched pool of low-abundance proteins enable improved resolution and a compressed dynamic range for biomarker discovery experiments using label-free shotgun profiling with LC-MS/MS analysis, as well as two-dimensional gel-based techniques. Immuno-depletion of clinical samples has facilitated the discovery of many candidate biomarkers and is now routinely used as a robust strategy to help overcome some of the problems associated with dynamic range [87, 88]. However, immunodepletion is not without some drawbacks. One of the most significant problems is the co-depletion of many low-abundance proteins during the processing of samples as a consequence of non-specific binding to antibodies or through their interactions with highly abundant proteins such as albumin. This is known as the carrier-and-cargo effect. Importantly, Yadav et al. [89] identified 101 proteins with high confidence in the bound fractions from three plasma samples depleted using each of the three multi-affinity removal system MARS cartridges, e.g. Hu-6, Hu-14 and Proteoprep 20 . Such results strongly suggest it may be prudent to analyse both high and low abundant fractions to maximize the overall detection rate and quantification of as many plasma-associated proteins as possible.

Hexapeptide libraries, such as ProteoMiner ${ }^{\mathrm{TM}}$ protein enrichment technology, can substantially increase the sensitivity of shotgun proteomic analyses of complex biofluid samples [90, 91]. Dynamic range compression is a result of high abundant proteins quickly saturating their specific ligands while mediumand low-abundant proteins continue to bind to their 
ligands, resulting in a significant dilution of highabundance proteins while low-abundance molecules are concentrated. The ProteoMiner ${ }^{\mathrm{TM}}$ technology is based on a combinatorial library of hexapeptides bound to a chromatographic support. The vast ligand diversity based on 64 million unique beads generated offers in theory a ligand for every protein present in the starting material. Currently, hexapeptide libraries have been mostly used to increase proteomic detection in biofluid samples such as serum and plasma, although Candiano and co-workers [92] reported that at least 3,300 protein spots could be visualized in a two-dimensional gel map from urine using a modified ProteoMiner ${ }^{\mathrm{TM}}$ enrichment approach.

Degradation of protein biomarkers can occur immediately following the collection of biofluids as a result of endogenous or exogenous proteinase activity. To overcome this issue, nanoparticles or nanotraps are able to concentrate and protect sensitive protein populations. This approach uses a combination of size exclusion and affinity capture methodology to enrich for low-molecular-mass proteins [93, 94]. Both the size exclusion and affinity capture components of the nanotraps are adjustable, therefore allowing researchers to screen their clinical samples using a panel of molecular baits to capture many disease-related proteins present in the starting material. The suitability of this technology is exemplified by a recent study with polynanoparticles that reliably measured a low-abundance protein analyte, the human growth hormone $\mathrm{HGH}$ in urine [95]. This demonstrates how the match of specific bait chemistry can be exploited to capture a certain analyte. Traditional fractionation techniques are also very effective at helping to increase the coverage of biofluid proteomes, including chromatography approaches such as cation exchange, anion exchange, one-dimensional polyacrylamide gel electrophoresis and $\mathrm{ZOOM}^{\circledR}$ isoelectric focusing pre-fractionation procedures [96-98]. Indeed, combinations of two or more fractionation techniques have been employed by some groups to generate many fractions, helping to reduce sample complexity and enhance the ability to identify low concentration biomolecules $[99,100]$.

\section{PROTEOMIC ANALYSIS OF MUSCULAR DYSTROPHY}

\section{Proteomic profiling of dystrophin and dystrophic muscle tissues}

The primary deficiency in the membrane cytoskeletal protein dystrophin is the underlying cause of
X-linked muscular dystrophy [101]. In normal muscle, dystrophin forms a large complex with several sarcolemmal proteins, including dystroglycans, sarcoglycans, dystrobrevins, syntrophins and sarcospan [102-104]. Figure 3 summarizes the proteins linked to dystrophin at the interface between the subsarcolemmal cytoskeleton and the basal lamina and also outlines the relationship of the dystrophin-glycoprotein complex to other surface networks based on integrins and spectrin located in the plasmalemma, as well as utrophin at the neuromuscular junction $[105,106]$. In addition, major contractile and regulatory proteins of the actomyosin apparatus, elements of intermediate filaments and the lamin-associated nuclear membrane complex are listed. Since direct or indirect connections exist between the various extracellular, sarcolemmal, cytoskeletal and contractile protein families, the absence of dystrophin and severe reduction in dystrophin-associated glycoproteins may also affect other components of the cytoskeleton, the contractile apparatus or the extracellular matrix [107, 108]. Thus, the leakage or release of proteins, protein fragments or peptides belonging to these cytoskeletal or contractile protein networks may be exploitable as muscle-derived biomarkers of muscular dystrophy. A large number of candidate proteins that are potentially altered in dystrophinopathies are listed in Fig. 3.

Mass spectrometry-based proteomics has been widely applied to studying isolated components of the dystrophin-glycoprotein complex [109-112] and dystrophic muscle samples and biofluids. This has included established animal models of muscular dystrophy [113-117] and patient specimens. Global changes in muscle-associated proteins were determined using serum samples from the $m d x$ mouse $[118,119]$ and Duchenne patients [120-122], the secretome of $m d x$ myotubes [123], Duchenne muscle biopsies [124], the cytosolic $m d x$ muscle fraction [125, 126], microsomes from $m d x$ leg muscle [127], crude $m d x$ hind limb muscle extracts [128], individual $m d x$ leg muscles including gastrocnemius, tibialis anterior, extensor digitorum longus, soleus, flexor digitorum brevis and interosseus muscles [129-132], mildly affected $m d x$ extraocular muscles [133, 134], the severely dystrophic $m d x$ diaphragm [134-139], the $m d x$ heart [140-142] and skeletal muscle extracts from the grmd dog [143].

Although the primary insult causing a diseasealtered state in muscular dystrophy is the loss in the dystrophin isoform Dp427 [101], assaying fulllength dystrophin is not necessarily the most suitable biomarker test. The reason for this is the fact that 

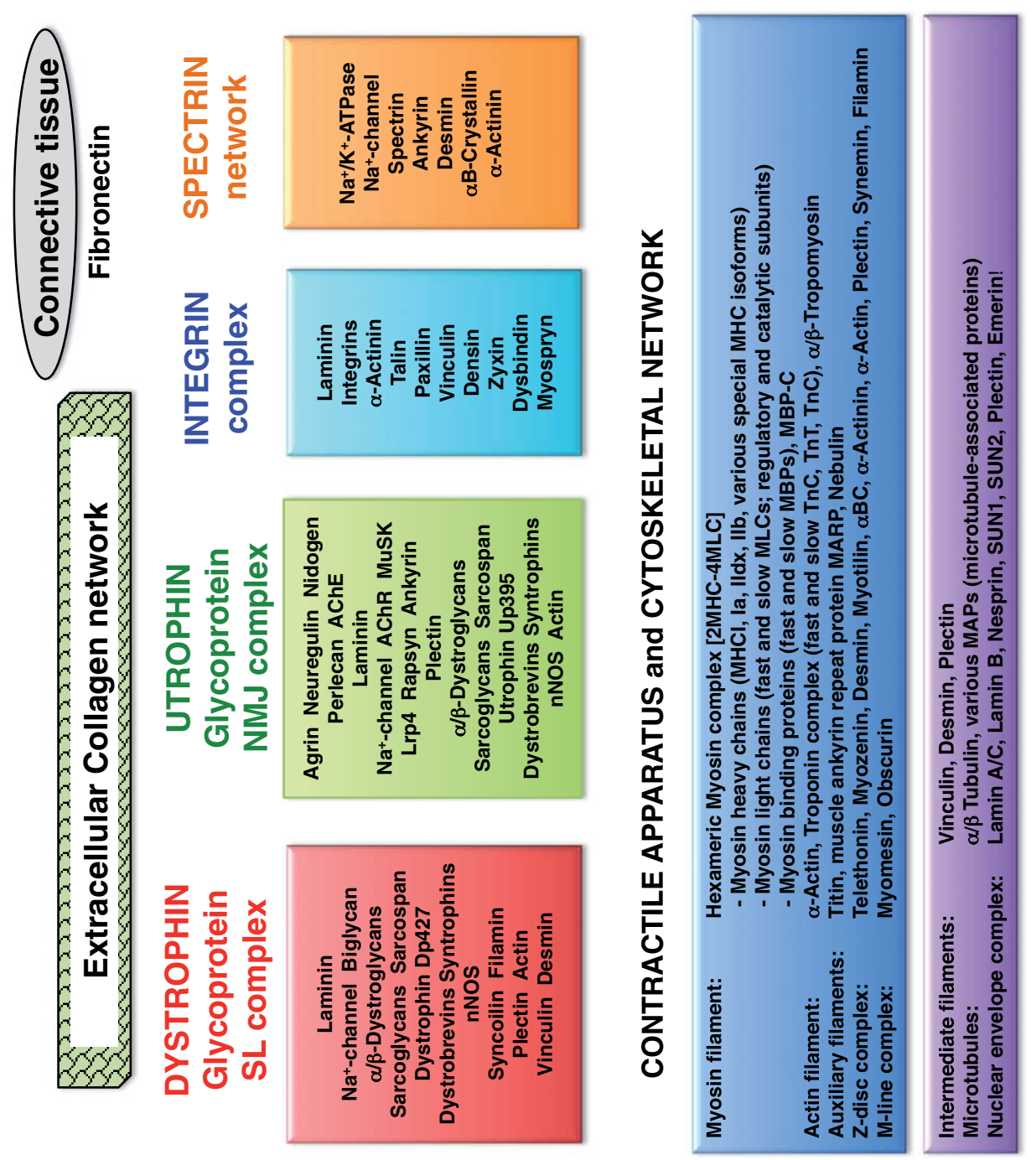

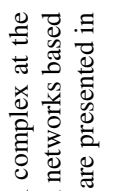

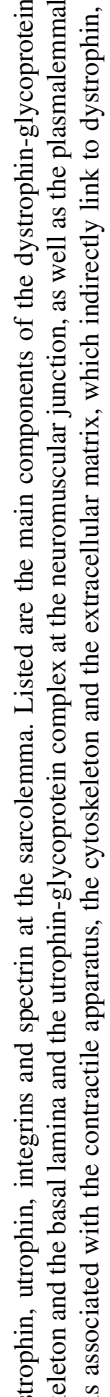

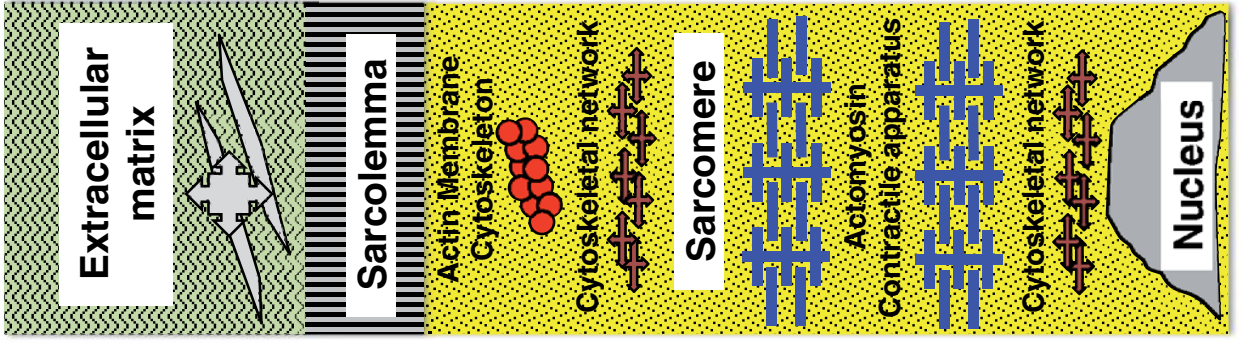




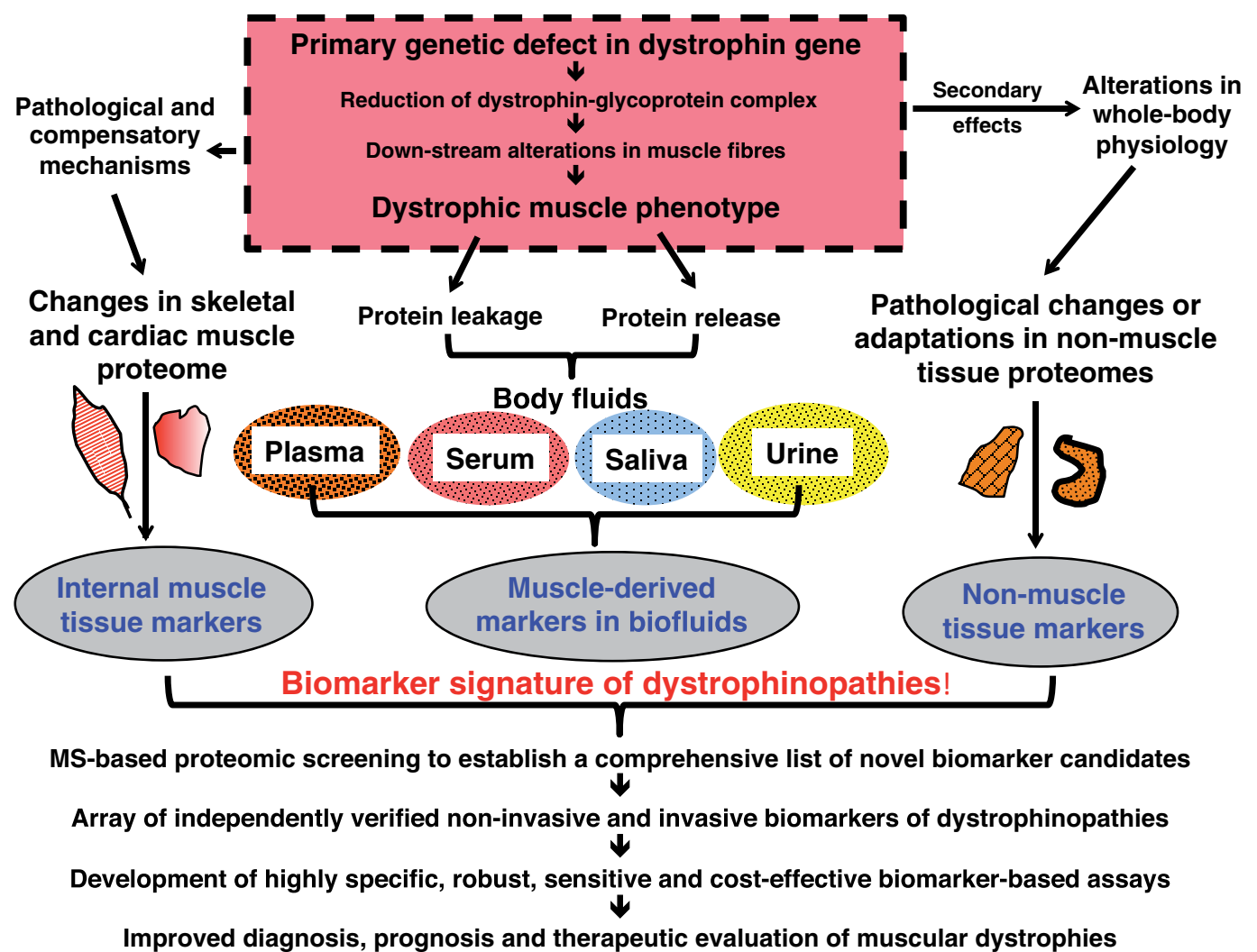

Fig. 4. Summary of the routine proteomic workflow for the swift identification of new dystrophinopathy-related biomarker candidates. Suitable biomarkers may be present in muscle fibres, muscle-associated but non-contractile tissues, non-muscle tissues or biofluids.

the primary abnormality in this essential membrane cytoskeletal protein may trigger irreversible changes in certain pathways and cellular signaling mechanisms during the impaired development of dystrophindeficient fibres. Therefore, the successful restoration of dystrophin in muscle fibres may not counter-act all dystrophy-related abnormalities. This might include the pathobiochemical consequences of progressive fibre degeneration, extensive fibrotic scaring and the extensive fatty tissue accumulation in dystrophic muscles. However, even if dystrophin substitution by pharmacological interventions or gene therapy does not reverse all secondary changes [144-146], alterations in the concentration of the Dp427 isoform could be employed as a pharmacodynamic biomarker that documents the successful reestablishment of the primary abnormality in dystrophinopathy [147]. Additional tests are then needed to evaluate the clinical value of therapeutic interventions, such as motor assessment, general physical examinations, histological tests and magnetic resonance imaging, as well as routine protein marker assays of downstream effects. This makes the identification of novel and reliable protein biomarkers an urgent task of muscle proteomics and warrants detailed investigations into proteome-wide changes in muscular dystrophy. Figure 4 summarizes the proteomic workflow for the identification of novel dystrophinopathy-specific biomarker candidates present in dystrophin-deficient muscle fibres, non-muscle tissues or suitable body fluids.

\section{Contractile and regulatory proteins of the actomyosin apparatus}

The proteomic screening of dystrophic muscle samples has revealed an altered concentration of the main contractile and regulatory proteins of the actomyosin apparatus. This includes myosin heavy chains, myosin light chains, troponin, tropomyosin and actin, as well as auxiliary proteins such as myosin binding protein, myozenin, myomesin and $\alpha$-actinin [126, 129-132, 134-139, 143]. The gel electrophoretic analysis of the cytosolic fraction of $m d x$ hind limb muscle revealed changes in myosin light chain MLC2 and tropomyosin 
[126], in conjunction with the drastic decrease in adenylate kinase isoform AK1 [125]. While moderate decreases in $\alpha$-actinin, fast myosin binding protein MBP-C, $\alpha$-actin and myosin heavy chains MHC IIx and MHCIIb were described to occur during the acute phase of dystrophin-deficiency in $m d x$ gastrocnemius muscle as determined by 2D-DIGE analysis [129], SILAC (stable isotope labeling by amino acids in cell culture) proteomics showed slight decreases in various myosin heavy chains, $\alpha$-actin and $\alpha / \beta$-tropomyosin [132]. Several other leg muscles exhibiting segmental necrosis were studied at a more advanced stage of muscular dystrophy. Proteomics revealed alterations in troponin $\mathrm{TnC}$, myosin binding protein MBP-C and myosin light chains MCL2 and MLC3 in soleus muscle, troponin TnT and myosin heavy chain in extensor digitorum longus muscle, troponin $\mathrm{TnI}$ and $\alpha / \beta$-tropomyosin in flexor digitorum brevis muscle and troponin TnI in interosseus muscle [131], as well as decreased $\alpha$-tropomyosin levels in aged $m d x$ tibialis anterior muscle [130]. Moderate differential expression levels were established for tropomyosin, myosin light chains MLC1, MLC2 and MLC3, various myosin heavy chains, myosin binding protein MBP$\mathrm{H}$, myotilin and myomesin in the dystrophic grmd dog model of Duchenne muscular dystrophy [143].

The severely dystrophic $m d x$ diaphragm showed changes in various myosin heavy and light chains, actin, troponins and actinin [134, 136-138]. Aged $m d x$ diaphragm muscle, which is characterized by a drastic increase in collagen [138], exhibited differential expression patterns of myosin light chains, tropomyosin, troponins, actin and nebulin [139]. Interestingly, the myosin light chain isoform MLC1 was identified in secreted LAMP1-associated vesicles [123], as described in below section on released biomarkers in biofluids. In contrast to relatively moderate and differential effects of dystrophin deficiency on skeletal muscles, the cardiac proteome showed unilateral decreases of many contractile proteins in muscular dystrophy-associated cardiomyopathy [141, 142]. The reduced abundance is especially striking for cardiac myosin light chain MLC2, as revealed by fluorescence 2D-DIGE analysis [141]. However, despite the many observed proteomic changes described in this section, it is currently difficult to establish alterations in a specific contractile protein as a suitable biomarker assay for dystrophinopathies. The high abundance and dynamic expression range of myosins and other contractile proteins complicate the development of sensitive tests for potential internal muscle markers. Probably, a panel of proteins belonging to the acto- myosin complex and its auxiliary structures would be more appropriate for evaluating complex dystrophyrelated changes in the contractile apparatus.

\section{Enzymes of energy metabolism}

The continuous provision of energy is essential for muscular activity making both the coordination and maintenance of anaerobic and aerobic bioenergetic pathways critical issues in contractile fibres $[148,149]$. Glycolytic enzymes and the mitochondrial subproteome make up a considerable part of the muscle protein constellation [4, 51-53]. Mitochondrial proteins account for approximately $20 \%$ of the skeletal muscle proteome [51] and the 10 glycolytic enzymes represent the most abundant proteins of the diffusible muscle fraction [150]. In general, muscle wasting is closely associated with alterations in bioenergetic provision and reflected by a variety of changes in glycolysis [151] and oxidative phosphorylation [152]. In dystrophinopathy, an impaired mitochondrial metabolism appears to be based on the pathophysiological uncoupling of oxidative phosphorylation and a considerable reduction in maximal ATP synthesis capacity [153]. This mitochondrial inefficiency and resulting decreased intramuscular ATP levels might be directly linked to a disrupted sub-sarcolemmal localization of mitochondria due to dystrophin deficiency in the actin membrane cytoskeleton [154].

Besides alterations in the localization and regulation of bioenergetic organelles and shifts in the concentration and/or isoform expression levels of metabolic enzymes, the abundance and availability of metabolite transporters and binding proteins may represent limiting factors of bioenergetic pathways. Therefore the transportation of glucose, amino acids, nucleotides, fatty acids and oxygen on the one hand and the efficient removal of waste products and $\mathrm{CO}_{2}$ on the other hand play an essential role in muscle metabolism [148]. Dystrophy-related changes in metabolite transportation or removal have been reported to occur on the level of myoglobin, fatty acid binding protein FABP3 and carbonic anhydrase CA3. While aged $m d x$ diaphragm muscle has drastically lowered levels of fatty acid binding protein and myoglobin [139], the aged $m d x$ tibialis anterior muscle showed high concentrations of carbonic anhydrase [130]. This indicates impaired utilization of fatty acids for oxidative metabolism in severely dystrophic fibres and apparently an additional need to remove excess $\mathrm{CO}_{2}$ from dystrophic muscles. Muscle proteins involved in lipid metabolism, mitochondrial bioenergetics, glycogen storage, glycol- 
ysis, gluconeogenesis and nucleotide metabolism have shown a generally perturbed expression pattern, but no clear unilateral shifts between anaerobic and aerobic metabolism are evident. However, since many muscle proteins are probably multi-functional, it is difficult to interpret individual changes within bioenergetic pathways and their implications for overall metabolic changes during muscle wasting.

Mitochondrial and glycolytic enzymes were shown to display both increased and decreased concentration levels in dystrophic muscles. Interestingly, the enzyme aldolase has been shown to be reduced in almost all subtypes of skeletal muscles in dystrophic mouse or dog models of Duchenne muscular dystrophy [129, 131, 134, 136, 137, 143]. During glycolysis, an aldolase-mediated reversible reaction brakes down fructose-1,6-biphosphate into glyceraldehyde-3-phosphate and dihydroxyacetone phosphate [151]. The gluconeogenic enzyme fructose1,6-biphosphatase appears to form complexes with aldolase in conjunction with $\alpha$-actinin on both sides of the Z-line of muscle fibres [155]. This physical linkage between key enzymes of glycolysis and gluconeogenesis probably enables efficient substrate channeling between these metabolic enzymes [156]. The decrease in aldolase in dystrophic muscle was reversed after experimental exon-skipping therapy, suggesting this glycolytic enzyme as a potential internal muscle marker of metabolic adaptations in muscular dystrophy [137]. The mitochondrial enzyme isocitrate dehydrogenase exhibits also a significantly reduced expression in dystrophic $m d x$ diaphragm and gastrocnemius muscle [132, 136] and exon-skipping intervention counter-acts the loss in this critical protein of the citric acid cycle [137]. Thus, both key enzymes of the sarcoplasmic fraction and the mitochondrial matrix may be useful as pharmacodynamic biomarkers in future gene therapy trials.

Numerous proteomic studies have convincingly shown alterations in the nucleotide metabolism of dystrophic muscles. The AK1 isoform of adenylate kinase and mitochondrial creatine kinase are reduced in dystrophic skeletal and cardiac muscles [125, 126, 135-137, 139, 141]. These proteomic findings were verified by immunoblot analysis [125, 137]. Hence, muscle nucleotide metabolism that involves the enzymatic activities of creatine kinase and adenylate kinase seems to be altered in dystrophin-deficient fibres. Experimental exon skipping therapy reversed the reduction in both enzymes [137], establishing adenylate kinase $\mathrm{AK} 1$ and the mitochondrial form of creatine kinase as potential muscle-associated biomarker can- didates for the evaluation of therapy and disease monitoring of progressive skeletal muscle wasting and cardiomyopathic complications associated with $\mathrm{X}$-linked muscular dystrophy. In contrast to reduced levels of enzymes of nucleotide metabolism, proteins involved in iron metabolism were shown to be increased in muscular dystrophy.

The comparative proteomic analysis of the contractile protein-depleted microsomal fraction from normal versus dystrophic skeletal muscle revealed an increase in ferritin and transferrin [127]. A moderate elevation in transferrin was also show in the acute phase of dystrophin deficiency of young $m d x$ muscle [129] and the aging $m d x$ heart exhibited drastic increases in ironregulatory proteins [142]. Ferritin is a ubiquitous intracellular iron-binding protein involved in iron detoxification and iron reserve by sequestering and releasing iron in a highly regulated way. Transferrin serves as a circulating protein, which delivers iron to tissue proteins [157]. The elevated levels of iron-binding proteins indicate disturbed iron homeostasis in dystrophindeficient fibres and might counter-act a potential iron overload in muscular dystrophy. The fact that all mammalian cells require proper regulation of iron levels for metabolic maintenance makes the concentration of transferrin and ferritin crucial indicators of potential adaptations or impairments in iron absorption and usage [158]. This might make iron-binding proteins also suitable metabolic biomarker candidates for evaluating the status of X-linked muscular dystrophy.

\section{Proteins involved in excitation-contraction coupling and ion homeostasis}

Excitation-contraction uncoupling and abnormal $\mathrm{Ca}^{2+}$-fluxes through the dystrophin-deficient plasmalemma, as well as impaired $\mathrm{Ca}^{2+}$-shuttling and lowered $\mathrm{Ca}^{2+}$-buffering capacities in the cytosol and the lumen of the sarcoplasmic reticulum are major contributory factors of secondary alterations in muscular dystrophy [159]. The calcium hypothesis of muscular dystrophy assumes that abnormal calcium homeostasis in mechanically stressed muscle cells plays a key role in contractile weakness. Biochemical, physiological and proteomic studies have confirmed unbalanced ion cycling through the sarcolemma of dystrophic fibres and an impaired $\mathrm{Ca}^{2+}$-buffering capacity of the terminal cisternae region of the sarcoplasmic reticulum [128, 134, 135, 139, 160-164]. Abnormal $\mathrm{Ca}^{2+}$-handling may contribute in a major fashion to an enhanced level of muscle protein degradation [165, 166]. The normal movement of $\mathrm{Ca}^{2+}$-ions, which 
present one of the most critical second messenger molecules in skeletal muscle, is maintained under precise temporal and spatial control by the highly regulated interactions between $\mathrm{Ca}^{2+}$-channels, $\mathrm{Ca}^{2+}$ shuttle proteins, $\mathrm{Ca}^{2+}$-binding proteins, $\mathrm{Ca}^{2+}$-release units, ion exchangers, $\mathrm{Ca}^{2+}$-pumping ATPases and voltage-sensing receptors [167]. Disturbances of this complex physiological system, which indirectly regulates many metabolic and signaling mechanisms, may result in severe fibre degeneration.

Dysregulation of excitation-contraction coupling and muscle relaxation due to an anomalous intracellular accumulation of $\mathrm{Ca}^{2+}$-ions and resulting chronic $\mathrm{Ca}^{2+}$-overload is believed to cause disintegration of sarcolemmal integrity by activating $\mathrm{Ca}^{2+}$-dependent proteolytic processes [159, 166]. Micro-rupturing of the dystrophin-deficient sarcolemma triggers a $\mathrm{Ca}^{2+}$ related membrane re-sealing process that in turn initiates the introduction of sarcolemmal patches containing $\mathrm{Ca}^{2+}$-leak channels that provide an increased influx of $\mathrm{Ca}^{2+}$-ions into the sarcoplasm of dystrophic fibres [164]. The comparative biochemical and proteomic profiling of dystrophic muscle versus wild type has shown decreased levels of the $\mathrm{Ca}^{2+}$-binding proteins parvalbumin, regucalcin, calsequestrin, calsequestrin-like proteins and sarcalumenin $[128,134,135,139,162,163]$. The proteomic analysis of experimental exon skipping clearly showed a reversal of the reduced levels of fast calsequestrin following anti-sense treatment of the $m d x$ diaphragm muscle [137]. This makes changes in the concentration of the cytosolic $\mathrm{Ca}^{2+}$-binding proteins parvalbumin [139] and regucalcin [135], the luminal $\mathrm{Ca}^{2+}$-shuttle protein sarcalumenin [162], the calsequestrin-like proteins of high molecular mass named CLP1 to CLP5 [163] and the fast $63 \mathrm{kDa}$ isoform of the luminal $\mathrm{Ca}^{2+}$. binding protein calsequestrin [128, 134, 139] suitable biomarker candidates for the monitoring of changes in $\mathrm{Ca}^{2+}$-handling in dystrophic skeletal muscle.

\section{Cytoskeletal and extracellular matrix proteins}

The dystrophin-glycoprotein complex links the outside of the muscle fibre via the trans-sarcolemmal dystroglycan sub-complex to the internal actin cytoskeleton [104, 106, 108]. In both, $m d x$ mouse muscle and skeletal muscle biopsies from Duchenne patients, the deficiency in dystrophin isoform Dp427 results in a drastic reduction in all dystrophinassociated glycoproteins [102, 168, 169]. However, the extracellular matrix protein laminin is not affected by the primary abnormality in dystrophin [139] and the cytoskeletal protein spectrin is also not altered in its concentration in muscular dystrophy $[168,169]$. This makes laminin and spectrin suitable marker proteins for equal loading controls in comparative biochemical studies of dystrophic versus wild type skeletal muscle specimens. However, in the dystrophic heart, laminin was shown to be drastically reduced. Label-free mass spectrometry revealed lower levels of laminin and nidogen in the aged $m d x$ heart and these findings were confirmed by immunoblot analysis [142]. The dystrophic heart exhibits a variety of differences in its secondary abnormalities as compared to dystrophindeficient skeletal muscle tissues [170], and possibly the differing subcellular localization of the cardiac dystrophin complex might play a role in the drastic loss of laminin. In the heart, dystrophin and its associated glycoproteins are located in both the sarcolemma and the transverse tubules, while the skeletal muscle complex is restricted to the sarcolemma and junctional folds of the neuromuscular junction region. Thus, the measurement of laminin levels might be a useful indicator for the differential evaluation of muscular dystrophy versus dystrophy-related cardiomyopathy.

Numerous proteomic studies indicate that the concentration of the extracellular matrix protein collagen and the cytoskeletal proteins vimentin, desmin and tubulin are increased in dystrophinopathies [129, 132, $134,136,138,139]$. Proteomic profiling and comparative immunoblotting of the fibrotic status of the aged $m d x$ diaphragm revealed a drastic increase of the extracellular matrix proteins collagen and dermatopontin [138]. Although the natural aging process of the musculature is associated with higher collagen levels [171], senescent fibres lacking dystrophin exhibit a several times elevated level of collagen [138]. The increased density of the intermediate filament proteins vinculin and desmin and the main microtubule-forming component tubulin indicate compensatory mechanisms to counter-act the structural weakness of the cytoskeletal network in dystrophic fibres [129, 132, 136]. Interestingly, desmin, vimentin and actin form complexes with $\alpha \mathrm{B}$-crystallin-like chaperones in contractile tissues during prolonged periods of cellular stress [172]. Small heat shock proteins appear to be directly involved in the modulation of intermediate filament assembly. Although vimentin appears to be only transiently expressed during myotube maturation [173], the concomitant increase in desmin and the molecular chaperone cvHSP, as discussed in more detail below, strongly suggests a stabilizing function through increased levels of this cytoskeletal element. The additional support of microtubules and interme- 
diate filaments might at least partially substitute for the loss of dystrophin in the impaired actin membrane cytoskeleton.

In addition, the dystrophic $m d x$ heart is characterized by a reduction in the protein lamin of the nuclear envelope complex [142]. The reduced presence of lamin may drastically weaken the linkage between the lamin network and its associated proteins nesprin, SUN1, SUN2 and plectin at the interface between muscle nuclei and the cytoskeleton [174]. With respect to biomarker discovery for dystrophinopathies, the proteomic identification of altered concentration levels in distinct cytoskeletal proteins suggests desmin, vimentin, tubulin and lamin as potential candidates for developing diagnostic tests for the differential analysis of muscular dystrophy.

\section{Molecular chaperones}

During both normal contractile activities and pathological conditions, considerable cellular stress is exerted on the neuromuscular system. Therefore, the continued preservation of muscle proteostasis is at the core of protecting and adapting contractile tissues. This includes on the one hand the maintenance of correct protein folding, efficient protein transportation and appropriate protein complex arrangements to provide the structural basis for diverse muscle functions, and on the other hand the effective removal of misfolded proteins during extended periods of pathological adaptations or cellular stress [175]. In skeletal muscle, various molecular chaperones are involved in protein stabilization by supporting the correct functional fold of peptide domains and eliminate non-functional protein aggregations [176]. Besides protein disulfide isomerase, peptidyl prolyl isomerase, calreticulin and calnexin, a large number of heat shock proteins (HSP) are involved in the cellular stress response [177]. Muscle-specific expression was shown for low-molecular mass HSP molecules (HSPB), such as the $\alpha \mathrm{B}$-crystallin like cardiovascular HSP (HSPB7, cvHSP) [178]. HSPs with higher molecular masses are represented by HSP40 (DNAJ), HSP60 (HSPD), HSP70 (HSPA) and its co-chaperones, HSP90 (HSPC) and HSP110 [176].

Pathobiochemical studies of dystrophic muscles have demonstrated an elevated concentration of HSP65 and HSP72 in hyper-contracted fibres from Duchenne patients [179] and increases in HSP70 and HSP90 in tissue extracts from Duchenne muscle samples [180]. The experimental iron deprivation of $m d x$ muscle triggered a selective decrease in the over-expression of
HSP70, suggesting that the iron-associated generation of hydroxyl radicals may be linked to the severity of muscle necrosis and possibly modify the cellular stress response in dystrophinopathies [181]. The crucial role of HSPs in the molecular pathogenesis of muscular dystrophy is illustrated by the fact that exposure to the experimental drug BGP-15, which represents a pharmacological inducer of HSP72, clearly improves muscle structure and contractile strength in dystrophic $m d x$ and $d k o$ mice [182]. Since the up-regulation of HSP72 acts via the functional restoration of the sarcoplasmic reticulum $\mathrm{Ca}^{2+}$-ATPase [182] and transgenic overexpression of this enzyme has been shown to attenuate dystrophic features in $m d x$ fibres [183], most likely the restoration of a low cytosolic $\mathrm{Ca}^{2+}$-concentration and reversal of excess sarcolemmal $\mathrm{Ca}^{2+}$-influx is crucial in preventing muscle degeneration. Thus, molecular chaperones like HSP72 are essential factors for the cyto-protection of stressed fibres [182].

Proteomics has identified drastic changes in the expression of cvHSP (HSPB7), $\alpha$ BC (HSPB5), HSP70 (HSPA) and HSP90 (HSPC) in dystrophic muscles [126, 127, 129, 134, 136, 139], which qualifies some molecular chaperones as potential biomarkers of skeletal muscle degeneration [184]. In stressed muscle fibres, a highly complex system of protective pathways is concerned with the continuous maintenance of contractile and metabolic protein functions. Muscle protein protection and preservation involves the general support of protein homeostasis, the facilitation of three-dimensional protein folding into the native molecular state and the protection of proteome integrity. Therefore, progressive muscular dystrophy is associated with drastic changes in chaperoning molecules. Especially the class of small and relatively muscle-specific chaperones might be useful for diagnostic and prognostic purposes. It is encouraging that the molecular chaperone cvHsp has already been successfully employed for the biochemical evaluation of experimental exon skipping therapy [137]. A potential disadvantage of heat shock proteins is their intramuscular location, but the proteomic profiling of the secretome of $m d x$ myotubes suggests that the released chaperones HSP-5, HSP-8 and HSP90 may be suitable biomarker candidates in biofluids [123].

\section{Biotransformation enzymes}

The continued detoxification of potentially harmful substances, the biotransformation of xenobiotics and the anti-oxidant protection are natural defense mechanisms of muscle fibres and involve a variety of enzyme 
systems. It is therefore not surprising that free radical production, oxidative stress and impaired biotransformation has been suggested to play an important role in the molecular pathogenesis of dystrophinopathies [185-187]. As discussed in detail by Tidball and Wehling-Henricks [188], the loss of dystrophin and concomitant disintegration of its associated glycoprotein complex causes the disruption of free radicals production and this pathobiochemical alteration contributes in a major way to muscular degeneration. Possibly the disruption of cellular signaling mechanisms or a drastic shift in free radicals production is involved in cellular injury and resulting contractile weakness. The enzyme glutathione transferase is a crucial catalyst in glutathione-dependent phase 2 biotransformation reactions [189]. An increased concentration of both glutathione transferase and catalase was established to occur in the aged $m d x$ heart as judged by proteomic analysis [142].

These proteomic findings agree with elevated stress levels in dystrophinopathies and the idea that intensified protein oxidation by highly reactive free radical species causes cellular damage in both Duchenne patients and the $m d x$ mouse [186, 188]. Anti-oxidant and biotransformation mechanisms appear to involve both glutathione transferase and catalase in muscular dystrophy [189]. Since the experimental elevation of catalase concentration was shown to improve $m d x$ muscle functions [190], the observed high expression of catalase in dystrophic fibres might represent a major protective mechanism to decrease cellular injury in muscular dystrophies. The proteomic identification of significant changes in the concentration of glutathione transferase and catalase might thus be useful to establish especially a heart-specific biomarker signature of muscular dystrophy-related changes [170]. The general status of enzymes involved in anti-oxidant responses and detoxification processes can then be used for evaluating levels of biotransformation in dystrophic or pharmacologically treated muscles.

\section{MUSCLE DISEASE DIAGNOSTICS AND BIOMARKER DISCOVERY}

\section{Diagnosis of muscular dystrophy}

Motor assessment plays an important role in the evaluation of disease status in dystrophic patients [191-194]. In addition to the review of clinical history and physical examination, the conventional diagnosis of muscular dystrophies has heavily relied on electro-diagnostic testing, enzyme assays for the detection of muscle-related serum activity, the genetic evaluation of carriers and patients, the histological, histochemical and immunochemical evaluation of muscle biopsy specimens and the biochemical analyses of disease-related protein changes by gel electrophoresis and immunoblotting [71]. Since many of these routine tests are not very reliable, lack specificity with respect to differentiating between distinct neuromuscular pathologies and are invasive, there is great scope for the identification of superior diagnostic biomarkers of dystrophinopathies. A non-invasive alternative to muscle biopsy procedures is represented by magnetic resonance imaging and spectroscopy for the diagnosis and monitoring of disease progression, and potentially clinical outcome measures, in dystrophinopathies [195-197]. The clinical value of this imaging technique has been clearly demonstrated [198, 199] and a good correlation exists between skeletal muscle histology, as judged by the histochemical evaluation of muscle biopsies, and dystrophic changes observed by magnetic resonance imaging technology [200]. However, MRI scoring procedures require highly specialized equipment, are labor-intensive and often too expensive for routine screening programs. Hence, the development of a simple and cost-effective biomarker assay of a minimally invasive or non-invasive nature would overcome many of these financial and technical issues.

\section{Proteomic biomarker discovery}

With respect to developing dependable and non-invasive tests, large-scale mass spectrometric screening approaches are crucial for biomarker discovery in the area of muscular dystrophy research. This includes the development of reliable assay systems for the evaluation of disease initiation, pathological progression and the monitoring of therapeutic interventions. In addition, the proteomics-based discovery of diagnostically conclusive biomarker signatures of muscular diseases is crucial for an improved understanding of the molecular pathogenesis of individual disorders. Ideally, a panel of novel protein biomarkers of dystrophinopathies will be useful for initial disease diagnosis, prognostic evaluations and the continued assessment of therapy efficacies. The flowchart in Fig. 5 outlines the different classes of biomarkers needed for the proper monitoring of dystrophinopathies. The changed abundance of specific proteins, shifts in isoform expression patterns, modifications of protein-protein interactions, alterations in post-translational modifications, the degradation of 


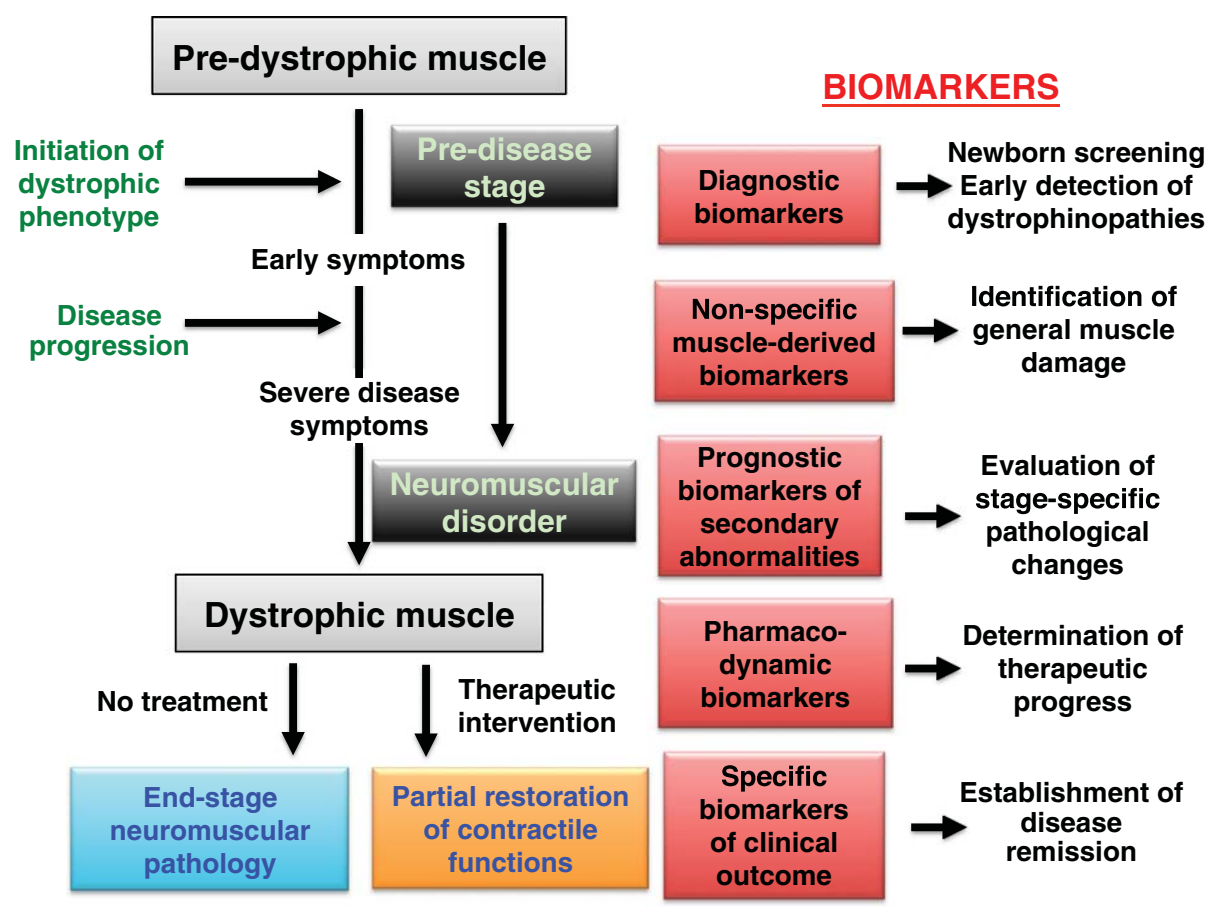

Fig. 5. Flowchart of the different classes of protein biomarkers that would be useful for the monitoring of dystrophinopathies. This includes the altered concentration of specific muscle-associated protein species, potential shifts in protein isoform expression patterns, modifications of protein-protein interactions, changes in post-translational modifications, the proteolytic degradation of proteins and/or the appearance of muscle-derived proteins, protein fragments or peptides in body fluids.

distinct proteins and/or the appearance of musclederived proteins, protein fragments or peptides in body fluids might also provide new insights into pathological mechanism of dystrophinopathies. Once significant changes in protein concentration, protein constellation and/or subcellular localization have been established by biochemical and proteomic studies, dependable biomarkers can then be tested for their overall diagnostic, prognostic or therapeutic potential. In general, a protein biomarker should ideally be (i) easily assessable, (ii) very sensitive, (iii) diagnostically conclusive, (iv) highly specific for subtypes of distinct disorders, (v) informative in relation to individual stages of disease progression and (vi) exhibit physicochemical properties that make a particular protein species suitable for the establishment of a meaningful and cost-effective test system [64].

If the novel biomarker is an internal muscleassociated protein, it should preferably be located in a relatively restricted cellular compartment under healthy conditions, exhibit an appropriate degree of fibre type specificity within affected whole skeletal muscles and show significant difference in density levels, subcellular expression and/or molecular features in dystrophic specimens versus normal muscle samples. However, if the novel biomarker is a musclederived protein that has leaked or been released from contractile fibres, it should differ substantially between its intracellular and extracellular presence in undamaged versus dystrophic muscle. The degree of the disease-related occurrence of muscle markers in body fluids should ideally correlate with the onset, intensity and length of muscular damage. Both, internal biomarkers requiring invasive biopsy procedures or biofluid-associated muscle markers that can be obtained by minimally invasive or non-invasive methods, should be able to differentiate between acute pathological insults and chronic tissue damage.

\section{Circulating biomarkers for monitoring general muscle damage}

In the case of routine testing of Duchenne patients and the evaluation of carrier detection rates, historically the most frequently used serum enzyme activity has been creatine kinase [201]. In addition to serum creatine kinase [202-208], other marker enzymes are represented by carbonic anhydrase [209-212], aldolase [213], adenylate kinase [214-216], lactate dehydrogenase [206, 207, 213] and pyruvate kinase 
[206, 208, 217, 218]. Assay systems were used with single enzyme activities or combinations of various muscle-derived enzymes in patient serum [206-208, $211,213]$. Besides the examining of disease progression in dystrophic children, screening approaches included fetal plasma [219, 220] and the blood analysis of newborns [204, 205, 221], as well as a large number of investigations into the evaluation of carrier status [222-226]. The combined testing of several serum markers has shown the potential of improved screening efficiency, such as the usage of creatine kinase, myoglobin and hemopexin for identifying Duchenne muscular dystrophy carriers [227]. Besides serum and plasma, the testing of urine and saliva might also be useful for future diagnostic testing [228-231]. Especially urine proteomics has great potential for discovering new disease indicators that are suitable for the establishment of simple and non-invasive assays [232]. The comparative profiling of the urine proteome has already identified several urinary biomarkers of physical activity [233] and muscle wasting during cancer cachexia [234].

\section{Muscle-derived proteins as specific markers of dystrophinopathies}

In addition to the above outlined inherent complications of tissue proteomics, the future application of diagnostic or prognostic biomarkers associated with the muscle interior, as identified by proteomic profiling of cell mixtures, would require the undesirable usage of invasive methodology. Therefore proteomic screening programmes increasingly focus on the systematic analysis of suitable body fluids for differential analyses. In the future, the mining of the biofluid proteome promises to play a key role in diagnostic biomarker discovery in blood plasma, serum, urine and saliva [235] and the identification of new therapeutic targets [236]. The underlying objective of searching for biofluid-associated biomarkers is based on the assumption that firstly damaged tissues, that exist in close proximity to certain biological fluids, have a tendency to actively release or passively leak proteins into their external environment, and secondly that the overall range and/or density of shed proteins relates to the degree of cellular damage. This might lead to the identification of robust and unambiguous biomarkers of high clinical value [237].

Since the identification and establishment of biofluid-based biomarkers is essential for improved diagnosis, enhanced approaches of risk stratification and the optimum management of pathological devel- opments, recently international efforts have intensified and initiated the systematic screening of suitable body fluids for muscle-derived proteins. However, in contrast to the large number of proteomic studies described in above sections that have analysed muscle tissue extracts or subcellular fractions [63], relatively few mass spectrometric investigations that focus on leaked or secreted proteins from dystrophic muscle tissues have been published [118-123]. Serum and plasma, examples of distal biofluids, are composed of components originating from cells throughout the entire body, including various hormones, enzymes, glycoproteins, and growth factors. The choice of using serum versus plasma under specific experimental conditions is both acceptable. However, the HUPO committee and its research partners recommend plasma as the preferred specimen taken from blood, because it was found to have less ex vivo degradation and much less variability than the protease-rich process of clotting that is associated with serum processing [238, 239]. Many research groups take the opportunity to examine both serum and plasma in order to increase the overall coverage of the blood proteome in their investigations [86, 240]. Identification of disease-specific biomarkers is challenging in these samples given how substantially diluted biomolecules are in a matrix containing components derived from practically all tissues in the body [241].

Using ProteoMiner ${ }^{\mathrm{TM}}$ beads to reduce the high dynamic range of the serum proteome from Duchenne muscular dystrophy, Becker muscular dystrophy, Bethlem myopathy, Myasthenia gravis and control groups, Martin et al. [122] found that fibronectin levels were significantly increased in Duchenne patients as compared to age-matched controls. In contrast, fibronectin levels in patients suffering from Becker muscular dystrophy, Bethlem myopathy or Myasthenia gravis were comparable to control levels. Fibronectin is a major component of the extracellular matrix with normal adult serum concentrations typically in the region of $220 \mu \mathrm{g} / \mathrm{ml}$. Tissue fibrosis, a characteristic of progressive X-linked muscular dystrophy, is generally considered to arise due to a failure of the normal wound response to cease, a process dependent on fibronectin in promoting cell adhesion and migration. The highly progressive elevation of fibronectin levels was also observed in longitudinal samples from Duchenne patients [122]. Besides fibronectin, interesting novel proteomic biomarker candidates of X-linked muscular dystrophy are the coagulation factor XIIIa and the matrix metalloproteinase MMP-9 [118-120]. It is important to note that no significant alterations of the serum concentration of collagen and laminin were 
found in Duchenne patients, showing that measuring these proteins is not useful for evaluating the extent of fibrosis in dystrophinopathies [242].

Traditional biochemical analyses have previously established elevated serum levels of tissue inhibitors of metalloproteinase-1 and transforming growth factor TGF-beta1 in Duchenne patients [243-246]. In addition, the proteomic screening of the secretome from $m d x$ myotubes has demonstrated the release of a variety of vesicle-related proteins [123]. The mass spectrometric analysis revealed that lysosome-associated membrane protein 1 (LAMP1) containing vesicles comprise myosin light chain MLC1 and cytoskeletal proteins that are over-secreted in dystrophic myotubes [123]. Since skeletal muscles are now considered a secretory organ that releases a variety of myokines [247], which are involved in signalling within the neuromuscular system and also other organs involved in bioenergetic provision, the detailed analysis of the muscle secretome promises opportunities both for diagnostic and therapeutic purposes [248]. The future screening of body liquids for muscle-derived peptides, protein fragments or intact proteins should be able to corroborate the already established proteomic findings and hopefully identify additional suitable biomarker candidates. An interesting new marker of general muscle damage is the protein Xin [249]. If Xin-like proteins would be identified as suitable markers of muscle damage severity in dystrophinopathies, in conjunction with released or leaked biomarkers, then the progressive nature of muscular dystrophy could be monitored in a more approachable fashion.

\section{CONCLUSIONS}

Biomarkers are measures of a biological state and are used as an indicator to determine and evaluate normal biological processes, pathogenic processes or pharmacological responses to therapeutic regimes. These biomarkers are produced either by the diseased tissue itself or by other neighbouring tissues in response to the presence of the disease or other associated conditions such as inflammation or the immune response. Mass spectrometry-based proteomic surveys of various muscles and body fluids, using both gel electrophoresis and/or liquid chromatography for large-scale protein separation, have identified a large number of potential biomarker candidates for the improved diagnostic evaluation of dystrophinopathies. The subcellular localization and disease-related concentration changes of major biomarker candidates of dystrophinopathies, as described in this review, are summarized in the diagrammatic presentation of Fig. 6. Listed are the major categories of protein families that have been identified by proteomics-based screening approaches in conjunction with biochemical and cell biological verification analyses. Besides the members of the dystrophin-glycoprotein complex (dystrophin Dp427, dystroglycans, sarcoglycans, dystrobrevins, syntrophins, sarcospan), the figure includes proteins involved in (i) muscle contraction and the cytoskeleton (myosin heavy chains, myosin light chains, troponins, tropomyosin; auxiliary filament proteins, and the cytoskeletal proteins desmin, vimentin and tubulin), (ii) excitation-contraction coupling and ion homeostasis (calcium binding proteins, ion channels), (iii) extracellular matrix (collagen), (iv) cellular stress response (molecular chaperones cvHsp, $\alpha$ B-crystallin, Hsp70, Hsp90), (v) bioenergetic and metabolic pathways (aldolase, isocitrate dehydrogenase, adenylate kinase, creatine kinase) and (vi) muscle-derived proteins in body fluids (fibronectin, coagulation factor XIIIa, matrix metalloproteinase MMP-9, transforming growth factor TGF $\beta 1$ ). General serum markers of muscle damage are represented by creatine kinase, carbonic anhydrase and adenylate kinase, but these enzymes lack a high degree of specificity. The unchanged expression levels of the membrane cytoskeletal protein spectrin can be used as a loading control in comparative studies of muscle specimens. Laminin levels can be employed as an unchanged protein in dystrophic skeletal muscle preparations, but not for the analysis of cardiac tissues since its abundance is greatly reduced in dystrophindeficient cardiac tissues.

In analogy to the dystrophic grmd dog, in the future more detailed subproteomic studies might be possible due to the development of larger animal models of dystrophinopathies. Recently, the successful generation of a pig model of X-linked muscular dystrophy was reported using the targeted deletion of exon 52 in the dystrophin gene of male pig cells and the subsequent generation of severely dystrophic offspring by nuclear transfer [250]. The new model of progressive Duchenne muscular dystrophy exhibits increased serum creatine kinase levels, impaired mobility, contractile weakness and a drastically reduced life span of pigs due to respiratory impairment. Future proteomic studies of dystrophindeficient pigs may provide new insights into the hierarchy of physiological derangements in severe muscular dystrophy and provide sufficiently large amounts of contractile tissue for detailed subproteomic 


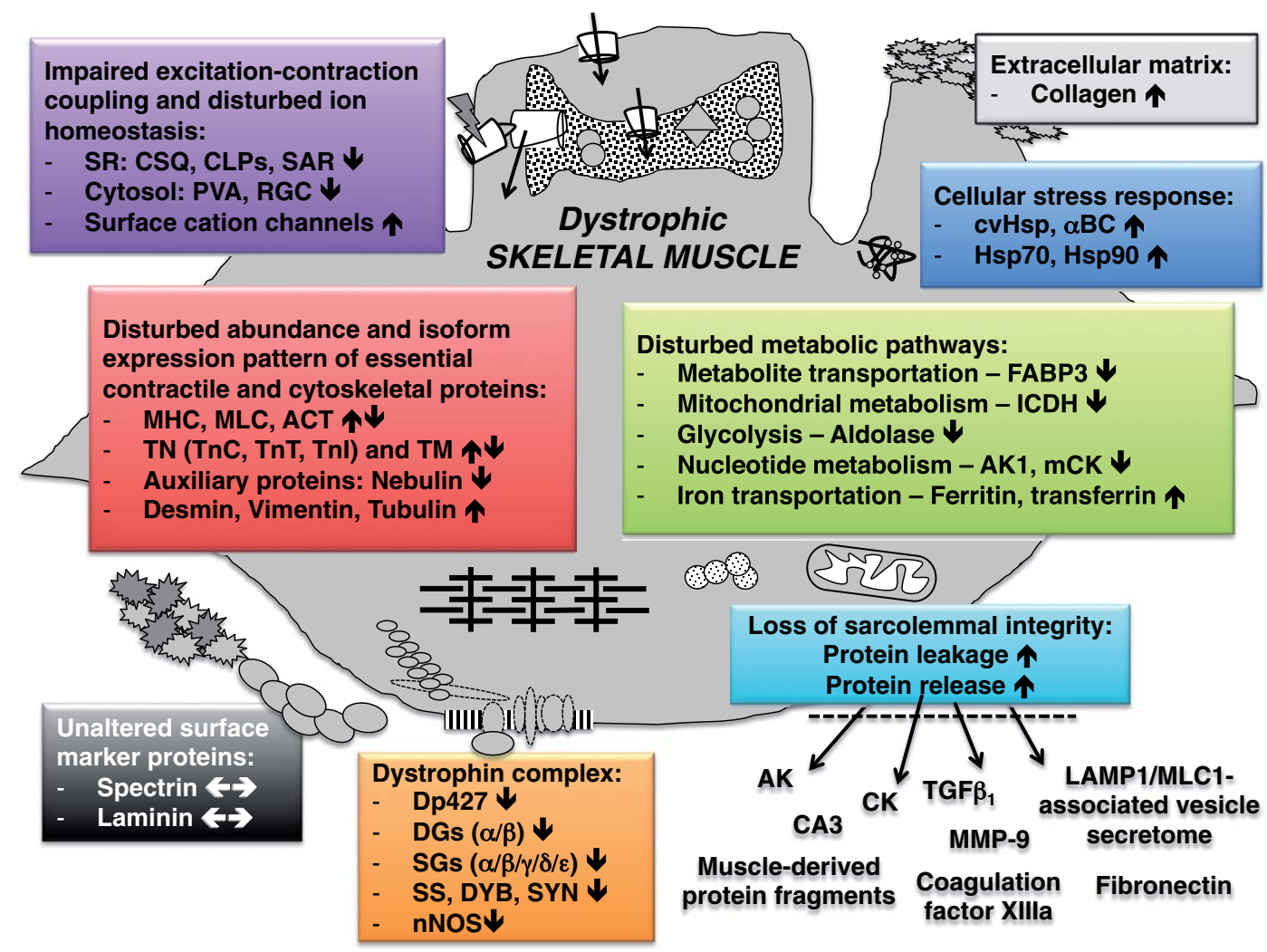

Fig. 6. Overview of the subcellular localization and disease-related concentration changes of major biomarker candidates of dystrophinopathies. This illustration summarizes the majority of protein families that have been identified by mass spectrometry-based proteomics as potential biomarker candidates.

studies of the sarcolemma, mitochondria, sarcoplasmic reticulum, transverse tubules and nuclei.

With respect to biomarker signatures on multiple biomolecular levels including ideally DNA, RNA, protein and metabolites, recent reports on musclespecific microRNAs and their suitability as minimally invasive serum biomarkers for Duchenne muscular dystrophy are encouraging [251-255]. The future combination of parallel tests that determine significant changes in muscle-associated proteomic biomarkers, muscle-derived proteins or protein fragments in body fluids, extracellular microRNAs and muscle metabolites appears to be the most appropriate approach for the comprehensive diagnostic, prognostic and therapeutic evaluation of X-linked muscular dystrophy.

\section{ACKNOWLEDGMENTS}

Research in the author's laboratory was supported by project grants from Muscular Dystrophy Ireland and the Irish Higher Education Authority (BioAT programme of PRTLI cycle 5).

\section{CONFLICT OF INTEREST}

The authors have no conflict of interest to report.

\section{REFERENCES}

[1] Gelfi, C., Vasso, M., and Cerretelli, P. Diversity of human skeletal muscle in health and disease: Contribution of proteomics. J Proteomics. 2011; 74(6): 774-795.

[2] Chan, C. Y., Masui, O., Krakovska, O., Belozerov, V. E., Voisin, S., Ghanny, S., Chen, J., Moyez, D., Zhu, P., Evans, K. R., McDermott, J. C., and Siu, K. W. Identification of differentially regulated secretome components during skeletal myogenesis. Mol Cell Proteomics. 2011; 10(5): M110.004804.

[3] Gelfi, C., Viganò, A., De Palma, S., Ripamonti, M., Begum, S., Cerretelli, P., and Wait, R. 2-D protein maps of rat gastrocnemius and soleus muscles: A tool for muscle plasticity assessment. Proteomics. 2006; 6(1): 321-340.

[4] Drexler, H. C., Ruhs, A., Konzer, A., Mendler, L., Bruckskotten, M., Looso, M., Günther, S., Boettger, T., Krüger, M., and Braun, T. On marathons and sprints: An integrated quantitative proteomics and transcriptomics analysis of differences between slow and fast muscle fibers. Mol Cell Proteomics. 2012; 11(6): M111.010801. 
[5] Holloway, K. V., O’Gorman, M., Woods, P., Morton, J. P., Evans, L., Cable, N. T., Goldspink, D. F., and Burniston, J. G. Proteomic investigation of changes in human vastus lateralis muscle in response to interval-exercise training. Proteomics. 2009; 9(22): 5155-5174.

[6] Hody, S., Leprince, P., Sergeant, K., Renaut, J., Croisier, J. L., Wang, F., and Rogister, B. Human muscle proteome modifications after acute or repeated eccentric exercises. Med Sci Sports Exerc. 2011; 43(12): 2281-2296.

[7] Egan, B., Dowling, P., O’Connor, P. L., Henry, M., Meleady, P., Zierath, J. R., and O'Gorman, D. J. 2-D DIGE analysis of the mitochondrial proteome from human skeletal muscle reveals time course-dependent remodelling in response to 14 consecutive days of endurance exercise training. Proteomics. 2011; 11(8): 1413-1428.

[8] Sharma, N., Medikayala, S., Defour, A., Rayavarapu, S., Brown, K. J., Hathout, Y., and Jaiswal, J. K. Use of quantitative membrane proteomics identifies a novel role of mitochondria in healing injured muscles. J Biol Chem. 2012; 287(36): 30455-30467.

[9] Oh, T. S., Choi, J. W., Choi, D. K., Mukherjee, R., Liu, H., and Yun, J. W. Gender dimorphism in skeletal muscle proteome between lean and diet-induced obese rats. Cell Physiol Biochem. 2011; 28(5): 981-996.

[10] Roca-Rivada, A., Al-Massadi, O., Castelao, C., Senín, L. L., Alonso, J., Seoane, L. M., García-Caballero, T., Casanueva, F. F., and Pardo, M. Muscle tissue as an endocrine organ: Comparative secretome profiling of slow-oxidative and fastglycolytic rat muscle explants and its variation with exercise. J Proteomics. 2012; 75(17): 5414-5425.

[11] Le Bihan, M. C., Bigot, A., Jensen, S. S., Dennis, J. L., Rogowska-Wrzesinska, A., Lainé, J., Gache, V., Furling, D., Jensen, O. N., Voit, T., Mouly, V., Coulton, G. R., and ButlerBrowne, G. In-depth analysis of the secretome identifies three major independent secretory pathways in differentiating human myoblasts. J Proteomics. 2012; 77(1): 344-356.

[12] Raschke, S., Eckardt, K., Bjørklund Holven, K., Jensen, J., and Eckel, J. Identification and validation of novel contraction-regulated myokines released from primary human skeletal muscle cells. PLoS One. 2013; 8(4): e62008.

[13] Donoghue, P., Doran, P., Wynne, K., Pedersen, K., Dunn, M. J., and Ohlendieck, K. Proteomic profiling of chronic lowfrequency stimulated fast muscle. Proteomics. 2007; 7(18): 3417-3430.

[14] Bouley, J., Meunier, B., Chambon, C., De Smet, S., Hocquette, J. F., and Picard, B. Proteomic analysis of bovine skeletal muscle hypertrophy. Proteomics. 2005; 5(2): 490500 .

[15] Moriggi, M., Cassano, P., Vasso, M., Capitanio, D., Fania, C., Musicco, C., Pesce, V., Gadaleta, M. N., and Gelfi, C. A DIGE approach for the assessment of rat soleus muscle changes during unloading: Effect of acetyl-L-carnitine supplementation. Proteomics. 2008; 8(17): 3588-3604.

[16] Moriggi, M., Vasso, M., Fania, C., Capitanio, D., Bonifacio, G., Salanova, M., Blottner, D., Rittweger, J., Felsenberg, D., Cerretelli, P., and Gelfi, C. Long term bed rest with and without vibration exercise countermeasures: Effects on human muscle protein dysregulation. Proteomics. 2010; 10(21): 3756-3774.

[17] De Palma, S., Ripamonti, M., Vigano, A., Moriggi, M., Capitanio, D., Samaja, M., Milano, G., Cerretelli, P., Wait, R., and Gelfi, C. Metabolic modulation induced by chronic hypoxia in rats using a comparative proteomic analysis of skeletal muscle tissue. J Proteome Res. 2007; 6(5): 19741984.
[18] Viganò, A., Vasso, M., Caretti, A., Bravatà, V., Terraneo, L., Fania, C., Capitanio, D., Samaja, M., and Gelfi, C. Protein modulation in mouse heart under acute and chronic hypoxia. Proteomics. 2011; 11(21): 4202-4217.

[19] Chen, K., Cole, R. B., and Rees, B. B. Hypoxia-induced changes in the zebrafish (Danio rerio) skeletal muscle proteome. J Proteomics. 2013; 78(1): 477-485.

[20] Capitanio, D., Vasso, M., Fania, C., Moriggi, M., Viganò, A., Procacci, P., Magnaghi, V., and Gelfi, C. Comparative proteomic profile of rat sciatic nerve and gastrocnemius muscle tissues in ageing by 2-D DIGE. Proteomics. 2009; 9(7): 2004-2020.

[21] Staunton, L., Zweyer, M., Swandulla, D., and Ohlendieck, $\mathrm{K}$. Mass spectrometry-based proteomic analysis of middleaged vs. aged vastus lateralis reveals increased levels of carbonic anhydrase isoform 3 in senescent human skeletal muscle. Int J Mol Med. 2012; 30(4): 723-733.

[22] Théron, L., Gueugneau, M., Coudy, C., Viala, D., Bijlsma, A., Butler-Browne, G., Maier, A., Béchet, D., and Chambon, C. Label-free Quantitative Protein Profiling of vastus lateralis Muscle During Human Aging. Mol Cell Proteomics. 2014; 13(1): 283-294.

[23] Hédou, J., Bastide, B., Page, A., Michalski, J. C. and Morelle, W. Mapping of O-linked beta-Nacetylglucosamine modification sites in key contractile proteins of rat skeletal muscle. Proteomics. 2009; 9(8): 2139-2148.

[24] Zhang, X., Højlund, K., Luo, M., Meyer, C., Geetha, T., and $\mathrm{Yi}, \mathrm{Z}$. Novel tyrosine phosphorylation sites in rat skeletal muscle revealed by phosphopeptide enrichment and HPLCESI-MS/MS. J Proteomics. 2012; 75(13): 4017-4026.

[25] Magherini, F., Abruzzo, P. M., Puglia, M., Bini, L., Gamberi, T., Esposito, F., Veicsteinas, A., Marini, M., Fiorillo, C., Gulisano, M., and Modesti, A. Proteomic analysis and protein carbonylation profile in trained and untrained rat muscles. J Proteomics. 2012; 75(3): 978-992.

[26] Su, D., Shukla, A. K., Chen, B., Kim, J. S., Nakayasu, E., Qu Y., Aryal, U., Weitz, K., Clauss, T. R., Monroe, M. E., Camp, D. G., 2nd, Bigelow, D. J., Smith, R. D., Kulkarni, R. N., and Qian, W. J. Quantitative site-specific reactivity profiling of S-nitrosylation in mouse skeletal muscle using cysteinyl peptide enrichment coupled with mass spectrometry. Free Radic Biol Med. 2013; 57:68-78.

[27] Lundby, A., Lage, K., Weinert, B. T., Bekker-Jensen, D. B., Secher, A., Skovgaard, T., Kelstrup, C. D., Dmytriyev, A., Choudhary, C., Lundby, C., and Olsen, J. V. Proteomic analysis of lysine acetylation sites in rat tissues reveals organ specificity and subcellular patterns. Cell Rep. 2012; 2(2): 419-431.

[28] Camerino, G. M., Pellegrino, M. A., Brocca, L., Digennaro, C., Camerino, D. C., Pierno, S., and Bottinelli, R. Statin or fibrate chronic treatment modifies the proteomic profile of rat skeletal muscle. Biochem Pharmacol. 2011; 81(8): 1054-1064.

[29] Han, N., Kim, H. D., Eom, M. J., You, J. M., Han, J., Kim, H. K., and Kang, M. S. Proteomic changes in rat gastrocnemius muscle after botulinum toxin a injection. Ann Rehabil Med. 2013; 37(2):157-166.

[30] Sato, Y., Shimizu, M., Mizunoya, W., Wariishi, H., Tatsumi, R., Buchman, V. L., and Ikeuchi, Y. Differential expression of sarcoplasmic and myofibrillar proteins of rat soleus muscle during denervation atrophy. Biosci Biotechnol Biochem. 2009; 73(8): 1748-1756

[31] Sun, H., Li, M., Gong, L., Liu, M., Ding, F., and Gu, X. iTRAQ-coupled 2D LC-MS/MS analysis on differentially 
expressed proteins in denervated tibialis anterior muscle of Rattus norvegicus. Mol Cell Biochem. 2012; 364(2): 193207.

[32] Staunton, L., Jockusch, H., and Ohlendieck, K. Proteomic analysis of muscle affected by motor neuron degeneration: The wobbler mouse model of amyotrophic lateral sclerosis. Biochem Biophys Res Commun. 2011; 406(4): 595-600.

[33] Capitanio, D., Vasso, M., Ratti, A., Grignaschi, G., Volta, M., Moriggi, M., Daleno, C., Bendotti, C., Silani, V., and Gelfi, C. Molecular signatures of amyotrophic lateral sclerosis disease progression in hind and forelimb muscles of an SOD1(G93A) mouse model. Antioxid Redox Signal. 2012; 17(10): 1333-1350.

[34] Mutsaers, C. A., Lamont, D. J., Hunter, G., Wishart, T. M., and Gillingwater, T. H. Label-free proteomics identifies Calreticulin and GRP75/Mortalin as peripherally accessible protein biomarkers for spinal muscular atrophy. Genome Med. 2013; 5(10): 95.

[35] Greenberg, S. A., Salajegheh, M., Judge, D. P., Feldman, M. W., Kuncl, R. W., Waldon, Z., Steen, H., and Wagner, K. R. Etiology of limb girdle muscular dystrophy 1D/1E determined by laser capture microdissection proteomics. Ann Neurol. 2012; 71(1): 141-145.

[36] Staunton, L., Jockusch, H., Wiegand, C., Albrecht, T., and Ohlendieck, K. Identification of secondary effects of hyperexcitability by proteomic profiling of myotonic mouse muscle. Mol Biosyst. 2011; 7(8): 2480-2489.

[37] Thingholm, T. E., Bak, S., Beck-Nielsen, H., Jensen, O. N., and Gaster, M. Characterization of human myotubes from type 2 diabetic and nondiabetic subjects using complementary quantitative mass spectrometric methods. Mol Cell Proteomics. 2011; 10(9): M110.006650.

[38] Giebelstein, J., Poschmann, G., Højlund, K., Schechinger, W., Dietrich, J. W., Levin, K., Beck-Nielsen, H., Podwojski, K., Stühler, K., Meyer, H. E., and Klein, H.H. The proteomic signature of insulin-resistant human skeletal muscle reveals increased glycolytic and decreased mitochondrial enzymes. Diabetologia. 2012; 55(4): 1114-1127.

[39] Yuan, H., Niu, Y., Liu, X., Yang, F., Niu, W., and Fu, L. Proteomic analysis of skeletal muscle in insulin-resistant mice: Response to 6-week aerobic exercise. PLoS One. 2013; 8(1): e53887.

[40] Hittel, D. S., Hathout, Y., Hoffman, E. P., and Houmard, J. A. Proteome analysis of skeletal muscle from obese and morbidly obese women. Diabetes. 2005; 54(5): 12831288 .

[41] Hwang, H., Bowen, B. P., Lefort, N., Flynn, C. R., De Filippis, E. A., Roberts, C., Smoke, C. C., Meyer, C., Højlund, K. Yi, Z., and Mandarino, L. J. Proteomics analysis of human skeletal muscle reveals novel abnormalities in obesity and type 2 diabetes. Diabetes. 2010; 59(1): 33-42.

[42] Sela, I., Milman Krentsis, I., Shlomai, Z., Sadeh, M., Dabby, R., Argov, Z., Ben-Bassat, H., and Mitrani-Rosenbaum, S. The proteomic profile of hereditary inclusion body myopathy. PLoS One. 2011; 6(1): e16334.

[43] Gomez, A. M., Vanheel, A., Losen, M., Molenaar, P. C., De Baets, M. H., Noben, J. P., Hellings, N., and MartinezMartinez, P. Proteomic analysis of rat tibialis anterior muscles at different stages of experimental autoimmune myasthenia gravis. J Neuroimmunol. 2013; 261(1): 141145.

[44] De Palma, S., Morandi, L., Mariani, E., Begum, S., Cerretelli, P., Wait, R., and Gelfi, C. Proteomic investigation of the molecular pathophysiology of dysferlinopathy. Proteomics. 2006; 6(1): 379-385.
[45] Feldkirchner, S., Schessl, J., Müller, S., Schoser, B., and Hanisch, F. G. Patient-specific protein aggregates in myofibrillar myopathies: Laser microdissection and differential proteomics for identification of plaque components. Proteomics. 2012; 12(23): 3598-3609.

[46] Maerkens, A., Kley, R. A., Olivé, M., Theis, V., van der Ven, P. F., Reimann, J., Milting, H., Schreiner, A., Uszkoreit, J., Eisenacher, M., Barkovits, K., Güttsches, A. K., Tonillo, J., Kuhlmann, K., Meyer, H. E., Schröder, R., Tegenthoff, M., Fürst, D. O., Müller, T., Goldfarb, L. G., Vorgerd, M., and Marcus, K. Differential proteomic analysis of abnormal intramyoplasmic aggregates in desminopathy. J Proteomics. 2013; 90(1): 14-27.

[47] Kley, R. A., Maerkens, A., Leber, Y., Theis, V., Schreiner, A., van der Ven, P. F., Uszkoreit, J., Stephan, C., Eulitz, S., Euler, N., Kirschner, J., Müller, K., Meyer, H. E., Tegenthoff, M., Fürst, D. O., Vorgerd, M., Müller, T., and Marcus, K. A combined laser microdissection and mass spectrometry approach reveals new disease relevant proteins accumulating in aggregates of filaminopathy patients. Mol Cell Proteomics. 2013; 12(1): 215-227.

[48] Tavichakorntrakool, R., Prasongwattana, V., Sriboonlue, P., Puapairoj, A., Pongskul, J., Khuntikeo, N., Hanpanich, W., Yenchitsomanus, P. T., Wongkham, C., and Thongboonkerd, V. Serial analyses of postmortem changes in human skeletal muscle: A case study of alterations in proteome profile, histology, electrolyte contents, water composition, and enzyme activity. Proteomics Clin Appl. 2008; 2(9): 1255-1264.

[49] Lewis, C., Carberry, S., and Ohlendieck, K. Proteomic profiling of $\mathrm{x}$-linked muscular dystrophy. J Muscle Res Cell Motil. 2009; 30(7): 267-279.

[50] Ohlendieck K. Skeletal muscle proteomics: Current approaches, technical challenges and emerging techniques. Skelet Muscle. 2011; 1(1): 6.

[51] Højlund, K., Yi, Z., Hwang, H., Bowen, B., Lefort, N., Flynn, C. R., Langlais, P., Weintraub, S. T., and Mandarino, L. J. Characterization of the human skeletal muscle proteome by one-dimensional gel electrophoresis and HPLC-ESIMS/MS. Mol Cell Proteomics. 2008; 7(2): 257-267.

[52] Raddatz, K., Albrecht, D., Hochgraefe, F., Hecker, M., and Gotthardt, M. A proteome map of murine heart and skeletal muscle. Proteomics. 2008; 8(9): 1885-1897.

[53] Parker, K. C., Walsh, R. J., Salajegheh, M., Amato, A. A., Krastins, B., Sarracino, D. A., and Greenberg, S. A. Characterization of human skeletal muscle biopsy samples using shotgun proteomics. J Proteome Res. 2009; 8(7): 32653277.

[54] Ohlendieck K. Organelle proteomics in skeletal muscle biology. J Integr OMICS. 2012; 2(2): 27-38.

[55] Ferreira, R., Vitorino, R., Alves, R. M., Appell, H. J., Powers, S. K., Duarte, J. A., and Amado, F. Subsarcolemmal and intermyofibrillar mitochondria proteome differences disclose functional specializations in skeletal muscle. Proteomics. 2010; 10(17): 3142-3154.

[56] Staunton, L., and Ohlendieck, K. Mass spectrometric characterization of the sarcoplasmic reticulum from rabbit skeletal muscle by on-membrane digestion. Protein Pept Lett. 2012; 19(3): 252-263.

[57] Liu, Z., Du, X., Yin, C., and Chang, Z. Shotgun proteomic analysis of sarcoplasmic reticulum preparations from rabbit skeletal muscle. Proteomics. 2013; 13(15): 23352338.

[58] Ohlendieck, K. Proteomics of skeletal muscle differentiation, neuromuscular disorders and fiber aging. Expert Rev Proteomics. 2010; 7(2): 283-296. 
[59] Ohlendieck, K. Proteomic profiling of skeletal muscle plasticity. Muscles Ligaments Tendons J. 2012; 1(4): 119-126.

[60] Burniston, J. G., and Hoffman, E. P. Proteomic responses of skeletal and cardiac muscle to exercise. Expert Rev Proteomics. 2011; 8(3): 361-377.

[61] Ohlendieck, K. Proteomics of exercise-induced skeletal muscle adaptations. OA Sports Medicine. 2013; 1(1): 3.

[62] Holland, A., and Ohlendieck, K. Proteomic profiling of the contractile apparatus from skeletal muscle. Expert Rev Proteomics. 2013; 10(3): 239-257.

[63] Holland, A., Carberry, S., and Ohlendieck, K. Proteomics of the Dystrophin-glycoprotein Complex and Dystrophinopathy. Curr Protein Pept Sci. 2013; 14(8): 680-697.

[64] Ohlendieck, K. Proteomic identification of biomarkers of skeletal muscle disorders. Biomark Med. 2013; 7(1): 169186.

[65] Lee, Y. H., Tan, H. T., and Chung, M. C. Subcellular fractionation methods and strategies for proteomics. Proteomics. 2010; 10(22): 3935-3956.

[66] Gatto, L., Vizcaíno, J. A., Hermjakob, H., Huber, W., and Lilley, K. S. Organelle proteomics experimental designs and analysis. Proteomics. 2010; 10(22): 3957-3969.

[67] Drissi, R., Dubois, M. L., and Boisvert, F. M. Proteomics methods for subcellular proteome analysis. FEBS J. 2013; 280(22): 5626-5634

[68] Schiaffino, S., and Reggiani, C. Fiber types in mammalian skeletal muscles. Physiol Rev. 2011; 91(4): 1447-1531.

[69] Altelaar, A. F., and Heck, A. J. Trends in ultrasensitive proteomics. Curr Opin Chem Biol. 2012; 16(2): 206-213.

[70] Ciciliot, S., Rossi, A. C., Dyar, K. A., Blaauw, B., and Schiaffino, S. Muscle type and fiber type specificity in muscle wasting. Int J Biochem Cell Biol. 2013; 45(10): 2191-2199.

[71] Dubowitz, V., Sewry, C. A., and Oldfors, A. Muscle Biopsy: A practical approach. 4th ed. Saunders Elsevier; 2013.

[72] Carp, S. J., Barr, A. E., and Barbe, M. F. Serum biomarkers as signals for risk and severity of work-related musculoskeletal injury. Biomark Med. 2008; 2(1): 67-79.

[73] Brancaccio, P., Lippi, G., and Maffulli, N. Biochemical markers of muscular damage. Clin Chem Lab Med. 2010; 48(6): 757-767.

[74] Hortin, G. L., Jortani, S. A., Ritchie, J. C., Jr., Valdes, R., Jr., and Chan, D. W. Proteomics: A new diagnostic frontier. Clin Chem. 2006; 52(7): 1218-1222.

[75] Zhang, A. H., Sun, H., Yan, G. L., Han, Y., and Wang, X. J. Serum proteomics in biomedical research: A systematic review. Appl Biochem Biotechnol. 2013; 170(4): 774-786.

[76] Ray, S., Reddy, P. J., Jain, R., Gollapalli, K., Moiyadi, A., and Srivastava, S. Proteomic technologies for the identification of disease biomarkers in serum: Advances and challenges ahead. Proteomics. 2011; 11(11): 2139-2161.

[77] Pieper, R., Gatlin, C. L., Makusky, A. J., Russo, P. S., Schatz, C. R., Miller, S. S., Su, Q., McGrath, A. M., Estock, M. A., Parmar, P. P., Zhao, M., Huang, S. T., Zhou, J., Wang, F., Esquer-Blasco, R., Anderson, N. L., Taylor, J., and Steiner, S. The human serum proteome: Display of nearly 3700 chromatographically separated protein spots on two-dimensional electrophoresis gels and identification of 325 distinct proteins. Proteomics. 2003; 3(7): 1345-1364.

[78] Hortin, G. L., and Sviridov, D. The dynamic range problem in the analysis of the plasma proteome. J Proteomics. 2010; 73(3): 629-636

[79] Zolotarjova, N., Mrozinski, P., Chen, H., and Martosella, J. Combination of affinity depletion of abundant proteins and reversed-phase fractionation in proteomic analysis of human plasma/serum. J Chromatogr A. 2008; 1189(2): 332-338.
[80] Pernemalm, M., Lewensohn, R., and Lehtiö, J. Affinity prefractionation for MS-based plasma proteomics. Proteomics. 2009; 9(6): 1420-1427.

[81] Apweiler, R., Aslanidis, C., Deufel, T., Gerstner, A., Hansen, J., Hochstrasser, D., Kellner, R., Kubicek, M., Lottspeich, F., Maser, E., Mewes, H. W., Meyer, H. E., Müllner, S., Mutter, W., Neumaier, M., Nollau, P., Nothwang, H. G., Ponten, F., Radbruch, A., Reinert, K., Rothe, G., Stockinger, H., Tarnok, A., Taussig, M. J., Thiel, A., Thiery, J., Ueffing, M., Valet, G., Vandekerckhove, J., Verhuven, W., Wagener, C., Wagner, O., and Schmitz, G. Approaching clinical proteomics: Current state and future fields of application in fluid proteomics. Clin Chem Lab Med. 2009; 47(6): 724-744.

[82] Teng, P. N., Bateman, N. W., Hood, B. L., and Conrads, T. P. Advances in proximal fluid proteomics for disease biomarker discovery. J Proteome Res. 2010; 9(12): 60916100.

[83] Zhang, Q., Faca, V., and Hanash, S. Mining the plasma proteome for disease applications across seven logs of protein abundance. J Proteome Res. 2011; 10(1): 46-50.

[84] Rosty, C., Christa, L., Kuzdzal, S., Baldwin, W. M., Zahurak, M. L., Carnot, F., Chan, D. W., Canto, M., Lillemoe, K. D., Cameron, J. L., Yeo, C. J., Hruban, R. H., and Goggins, M. Identification of hepatocarcinoma-intestinepancreas/pancreatitis-associated protein I as a biomarker for pancreatic ductal adenocarcinoma by protein biochip technology. Cancer Res. 2002; 62(6): 1868-1875.

[85] Ogata, Y., Charlesworth, M. C., and Muddiman, D. C. Evaluation of protein depletion methods for the analysis of total-, phospho- and glycoproteins in lumbar cerebrospinal fluid. J Proteome Res. 2005; 4(3): 837-845.

[86] Tang, H. Y., Beer, L. A., and Speicher, D. W. In-depth analysis of a plasma or serum proteome using a $4 \mathrm{D}$ protein profiling method. Methods Mol Biol. 2011; 728: 47-67.

[87] Milan, E., Lazzari, C., Anand, S., Floriani, I., Torri, V., Sorlini, C., Gregorc, V., and Bachi, A. SAA1 is over-expressed in plasma of non small cell lung cancer patients with poor outcome after treatment with epidermal growth factor receptor tyrosine-kinase inhibitors. J Proteomics. 2012; 76 (Special issue): 91-101.

[88] Rajpal, R., Dowling, P., Meiller, J., Clarke, C., Murphy, W. G., O'Connor, R., Kell, M., Mitsiades, C., Richardson, P., Anderson, K. C., Clynes, M., and O'Gorman, P. A novel panel of protein biomarkers for predicting response to thalidomide-based therapy in newly diagnosed multiple myeloma patients. Proteomics. 2011; 11(8): 1391-1402.

[89] Yadav, A. K., Bhardwaj, G., Basak, T., Kumar, D., Ahmad, S., Priyadarshini, R., Singh, A. K., Dash, D., and Sengupta, S. A systematic analysis of eluted fraction of plasma post immunoaffinity depletion: Implications in biomarker discovery. PLoS One. 2011; 6(9): e24442.

[90] Boschetti, E., and Righetti, P. G. The ProteoMiner in the proteomic arena: A non-depleting tool for discovering lowabundance species. J Proteomics. 2008; 71(3): 255-64.

[91] Righetti, P. G., and Boschetti, E. The ProteoMiner and the FortyNiners: Searching for gold nuggets in the proteomic arena. Mass Spectrom Rev. 2008; 27(6): 596-608.

[92] Candiano, G., Santucci, L., Bruschi, M., Petretto, A., D'Ambrosio, C., Scaloni, A., Righetti, P. G., and Ghiggeri, G. M. "Cheek-to-cheek" urinary proteome profiling via combinatorial peptide ligand libraries: A novel, unexpected elution system. J Proteomics. 2012; 75(3): 796-805.

[93] Geho, D. H., Jones, C. D., Petricoin, E. F., and Liotta, L. A. Nanoparticles: Potential biomarker harvesters. Curr Opin Chem Biol. 2006; 10(1): 56-61. 
[94] Luchini, A., Fredolini, C., Espina, B. H., Meani, F., Reeder, A., Rucker, S., Petricoin, E. F., 3rd., and Liotta, L. A Nanoparticle technology: Addressing the fundamental roadblocks to protein biomarker discovery. Curr Mol Med. 2010; 10(2):133-141.

[95] Luchini, A., Tamburro, D., Magni, R., Fredolini, C., Espina, V., Bosch, J., Garaci, E., Petricoin, E. F., 3rd., and Liotta, L. A. Application of Analyte Harvesting Nanoparticle Technology to the Measurement of Urinary HGH in Healthy Individuals. J Sports Med Doping Stud. 2012; 2(6): e127.

[96] Feig, M. A., Hammer, E., Völker, U., and Jehmlich, N. Indepth proteomic analysis of the human cerumen-a potential novel diagnostically relevant biofluid. J Proteomics. 2013; 83: 119-129.

[97] Richardson, M. R., Liu, S., Ringham, H. N., Chan, V., and Witzmann, F. A. Sample complexity reduction for two-dimensional electrophoresis using solution isoelectric focusing prefractionation. Electrophoresis. 2008; 29(12): 2637-2644.

[98] Sekigawa, I., Yanagida, M., Iwabuchi, K., Kaneda, K., Kaneko, H., Takasaki, Y., Jung, G., Sone, S., Tanaka, Y. Ogawa, H., and Takamori, K. Protein biomarker analysis by mass spectrometry in patients with rheumatoid arthritis receiving anti-tumor necrosis factor-alpha antibody therapy. Clin Exp Rheumatol. 2008;26(2): 261-267.

[99] Mortezai, N., Wagener, C., and Buck, F. Combining lectin affinity chromatography and immunodepletion - A novel method for the enrichment of disease-specific glycoproteins in human plasma. Methods. 2012; 56(2): 254-259.

[100] Vasudev, N. S., Ferguson, R. E., Cairns, D. A., Stanley, A J., Selby, P. J., and Banks, R. E. Serum biomarker discovery in renal cancer using 2-DE and prefractionation by immunodepletion and isoelectric focusing; increasing coverage or more of the same? Proteomics. 2008; 8(23): 5074-5085.

[101] Hoffman, E. P., Brown, R. H., Jr., Kunkel, L. M. Dystrophin: The protein product of the Duchenne muscular dystrophy locus. Cell. 1987; 51(6): 919-928.

[102] Ervasti, J. M., Ohlendieck, K., Kahl, S. D., Gaver, M. G., and Campbell, K. P. Deficiency of a glycoprotein component of the dystrophin complex in dystrophic muscle. Nature. 1990; 345(6273): 315-319.

[103] Ibraghimov-Beskrovnaya, O., Ervasti, J. M., Leveille, C. J., Slaughter, C. A., Sernett, S. W., Campbell, K. P. Primary structure of dystrophin-associated glycoproteins linking dystrophin to the extracellular matrix. Nature. 1992; 355(6362): 696-702.

[104] Ohlendieck, K. Towards an understanding of the dystrophinglycoprotein complex: Linkage between the extracellular matrix and the membrane cytoskeleton in muscle fibers. Eur J Cell Biol. 1996; 69(1): 1-10.

[105] Grounds, M. D., Sorokin, L., and White, J. Strength at the extracellular matrix-muscle interface. Scand J Med Sci Sports. 2005; 15(6): 381-391.

[106] Ervasti, J. M., and Sonnemann, K. J. Biology of the striated muscle dystrophin-glycoprotein complex. Int Rev Cytol. 2008; 265: 191-225.

[107] Gumerson, J. D., and Michele, D. E. The dystrophinglycoprotein complex in the prevention of muscle damage. J Biomed Biotechnol. 2011; 2011: 210797.

[108] Ervasti, JM. Dystrophin, its interactions with other proteins, and implications for muscular dystrophy. Biochim Biophys Acta. 2007; 1772(2): 108-117

[109] Lewis, C., and Ohlendieck, K. Mass spectrometric identification of dystrophin isoform Dp427 by on-membrane digestion of sarcolemma from skeletal muscle. Anal Biochem. 2010; 404(2): 197-203.

[110] Yoo, J. H., Johnson, E., Xu, R., Martin, L. T., Martin, P. T., and Montanaro, F. Comparative proteomic profiling of dystroglycan-associated proteins in wild type, $\mathrm{mdx}$, and Galgt 2 transgenic mouse skeletal muscle. J Proteome Res. 2012; 11(9): 4413-4424.

[111] Johnson, E. K., Zhang, L., Adams, M. E., Phillips, A., Freitas, M. A., Froehner, S. C., Green-Church, K. B., and Montanaro, F. Proteomic analysis reveals new cardiacspecific dystrophin-associated proteins. PLoS One. 2012; 7(8): e43515.

[112] Brown, K. J., Marathi, R., Fiorillo, A. A., Ciccimaro, E. F., Sharma, S., Rowlands, D. S., Rayavarapu, S., Nagaraju, K., Hoffman, E. P., and Hathout, Y. Accurate quantitation of dystrophin protein in human skeletal muscle using mass spectrometry. J Bioanal Biomed. 2012, 2012: Suppl. 7, 1-16.

[113] Watchko, J. F., O'Day, T. L., and Hoffman, E. P. Functional characteristics of dystrophic skeletal muscle: Insights from animal models. J Appl Physiol. 2002; 93(2): 407-417.

[114] Durbeej, M., and Campbell, K. P. Muscular dystrophies involving the dystrophin-glycoprotein complex: An overview of current mouse models. Curr Opin Genet Dev. 2002; 12(3): 349-361.

[115] Banks, G. B., and Chamberlain, J. S. The value of mammalian models for duchenne muscular dystrophy in developing therapeutic strategies. Curr Top Dev Biol. 2008; 84: 431-453.

[116] Kornegay, J. N., Bogan, J. R., Bogan, D. J., Childers, M. K., Li, J., Nghiem, P., Detwiler, D. A., Larsen, C. A., Grange, R. W., Bhavaraju-Sanka, R. K., Tou, S., Keene, B. P., Howard, J. F., Jr., Wang, J., Fan, Z., Schatzberg, S. J., Styner, M. A., Flanigan, K. M., Xiao, X., and Hoffman, E. P. Canine models of Duchenne muscular dystrophy and their use in therapeutic strategies. Mamm Genome. 2012; 23(2): 85-108.

[117] Partridge, T. A. The mdx mouse model as a surrogate for Duchenne muscular dystrophy. FEBS J. 2013; 280(17): 4177-4186.

[118] Alagaratnam, S., Mertens, B. J., Dalebout, J. C., Deelder, A. M., van Ommen, G. J., den Dunnen, J. T., 't Hoen, P. A. Serum protein profiling in mice: Identification of Factor XIIIa as a potential biomarker for muscular dystrophy. Proteomics. 2008; 8(8): 1552-1563.

[119] Colussi, C., Banfi, C., Brioschi, M., Tremoli, E., Straino, S., Spallotta, F., Mai, A., Rotili, D., Capogrossi, M. C., and Gaetano, C. Proteomic profile of differentially expressed plasma proteins from dystrophic mice and following suberoylanilide hydroxamic acid treatment. Proteomics Clin Appl. 2010; 4(1): 71-83.

[120] Nadarajah, V. D., van Putten, M., Chaouch, A., Garrood, P., Straub, V., Lochmüller, H., Ginjaar, H. B., Aartsma-Rus, A. M., van Ommen, G. J., den Dunnen, J. T., 't Hoen, P. A. Serum matrix metalloproteinase-9 (MMP-9) as a biomarker for monitoring disease progression in Duchenne muscular dystrophy (DMD). Neuromuscul Disord. 2011; 21(8): 569578.

[121] Nadarajah, V. D., Mertens, B. J. A., Dalebout, H., Bladergroen, M. R., Alagaratnam, S., Garrood, P., Bushby, K., Straub, V., Deelder, A. M., den Dunnen, J. T., van Ommen, G. J. B, 't Hoen, P. A. C., and van der Burgt, Y. E. M. Serum peptide profiles of Duchenne Muscular Dystrophy (DMD) patients evaluated by data handling strategies for high resolution content. J Proteomics Bioinform. 2012; 5:4.

[122] Martin, F. C., Hiller, M., Spitali, P., Oonk, S., Dalebout, H., Palmblad, M., Chaouch, A., Guglieri, M., Straub, V., 
Lochmüller, H., Niks, E. H., Verschuuren, J. J., AartsmaRus, A., Deelder, A. M., van der Burgt, Y. E., 't Hoen, P. A. Fibronectin is a serum biomarker for Duchenne muscular dystrophy. Proteomics Clin Appl. 2014; 8(3): 269-278.

[123] Duguez, S., Duddy, W., Johnston, H., Lainé, J., Le Bihan, M. C., Brown, K. J., Bigot, A., Hathout, Y., Butler-Browne, G., and Partridge, T. Dystrophin deficiency leads to disturbance of LAMP1-vesicle-associated protein secretion. Cell Mol Life Sci. 2013; 70(12): 2159-2174.

[124] Ramadasan-Nair, R., Gayathri, N., Mishra, S., Sunitha, B., Mythri, R. B., Nalini, A., Subbannayya, Y., Harsha, H. C., Kolthur-Seetharam, U., and Bharath, M. M. Mitochondrial alterations and oxidative stress in an acute transient mouse model of muscle degeneration: Implications for muscular dystrophy and related muscle pathologies. J Biol Chem. 2014; 289(1): 485-509.

[125] Ge, Y., Molloy, M. P., Chamberlain, J. S., and Andrews, P. C. Proteomic analysis of mdx skeletal muscle: Great reduction of adenylate kinase 1 expression and enzymatic activity. Proteomics. 2003; 3(10): 1895-1903.

[126] Ge, Y., Molloy, M. P., Chamberlain, J. S., and Andrews, P. C. Differential expression of the skeletal muscle proteome in mdx mice at different ages. Electrophoresis. 2004; 25(15): 2576-2585.

[127] Carberry, S., Zweyer, M., Swandulla, D., and Ohlendieck, K. Comparative proteomic analysis of the contractile proteindepleted fraction from normal versus dystrophic skeletal muscle. Anal Biochem. 2014; 446: 108-115.

[128] Doran, P., Dowling, P., Lohan, J., McDonnell, K., Poetsch, S., and Ohlendieck, K. Subproteomics analysis of $\mathrm{Ca}^{2+}$ binding proteins demonstrates decreased calsequestrin expression in dystrophic mouse skeletal muscle. Eur J Biochem. 2004; 271(19): 3943-3952.

[129] Gardan-Salmon, D., Dixon, J. M., Lonergan, S. M., and Selsby, J. T. Proteomic assessment of the acute phase of dystrophin deficiency in mdx mice. Eur J Appl Physiol. 2011; 111(11): 2763-2773.

[130] Carberry, S., Zweyer, M., Swandulla, D., and Ohlendieck, K. Profiling of age-related changes in the tibialis anterior muscle proteome of the mdx mouse model of dystrophinopathy. J Biomed Bioeng. 2012; 2012: 691641 .

[131] Carberry, S., Brinkmeier, H., Zhang, Y., Winkler, C. K., and Ohlendieck, K. Comparative proteomic profiling of soleus, extensor digitorum longus, flexor digitorum brevis and interosseus muscles from the mdx mouse model of Duchenne muscular dystrophy. Int J Mol Med. 2013; 32(3): 544-556.

[132] Rayavarapu, S., Coley, W., Cakir, E., Jahnke, V., Takeda, S., Aoki, Y., Grodish-Dressman, H., Jaiswal, J. K., Hoffman, E. P., Brown, K. J., Hathout, Y., and Nagaraju, K. Identification of disease specific pathways using in vivo SILAC proteomics in dystrophin deficient mdx mouse. Mol Cell Proteomics. 2013; 12(5): 1061-1073.

[133] Lewis, C., and Ohlendieck, K. Proteomic profiling of naturally protected extraocular muscles from the dystrophin-deficient mdx mouse. Biochem Biophys Res Commun. 2010; 396(4): 1024-1029.

[134] Matsumura, C. Y., Menezes de Oliveira, B., Durbeej, M., and Marques, M. J. Isobaric Tagging-Based Quantification for Proteomic Analysis: A Comparative Study of Spared and Affected Muscles from mdx Mice at the Early Phase of Dystrophy. PLoS One. 2013; 8(6): e65831.

[135] Doran, P., Dowling, P., Donoghue, P., Buffini, M., and Ohlendieck, K. Reduced expression of regucalcin in young and aged mdx diaphragm indicates abnormal cytosolic calcium handling in dystrophin-deficient muscle. Biochim Biophys Acta. 2006; 1764(4): 773-785.

[136] Doran, P., Martin, G., Dowling, P., Jockusch, H., and Ohlendieck, K. Proteome analysis of the dystrophindeficient MDX diaphragm reveals a drastic increase in the heat shock protein cvHSP. Proteomics. 2006; 6(16): 46104621.

[137] Doran, P., Wilton, S. D., Fletcher, S., and Ohlendieck, K. Proteomic profiling of antisense-induced exon skipping reveals reversal of pathobiochemical abnormalities in dystrophic mdx diaphragm. Proteomics. 2009; 9(3): 671-685.

[138] Carberry, S., Zweyer, M., Swandulla, D., and Ohlendieck, K. Proteomics reveals drastic increase of extracellular matrix proteins collagen and dermatopontin in the aged $\mathrm{mdx}$ diaphragm model of Duchenne muscular dystrophy. Int J Mol Med. 2012; 30(2): 229-234.

[139] Carberry, S., Zweyer, M., Swandulla, D., and Ohlendieck, K. Application of fluorescence two-dimensional difference in-gel electrophoresis as a proteomic biomarker discovery tool in muscular dystrophy research. Biology. 2013; 2(4): 1438-1464.

[140] Gulston, M. K., Rubtsov, D. V., Atherton, H. J., Clarke, K., Davies, K. E., Lilley, K. S., and Griffin, J. L. A combined metabolomic and proteomic investigation of the effects of a failure to express dystrophin in the mouse heart. J Proteome Res. 2008; 7(5): 2069-2077.

[141] Lewis, C., Jockusch, H., and Ohlendieck, K. Proteomic profiling of the dystrophin-deficient MDX heart reveals drastically altered levels of key metabolic and contractile proteins. J Biomed Biotechnol. 2010; 2010: 648501.

[142] Holland, A., Dowling, P., Zweyer, M., Swandulla, D., Henry, M., Clynes, M., and Ohlendieck, K. Proteomic profiling of cardiomyopathic tissue from the aged mdx model of Duchenne muscular dystrophy reveals a drastic decrease in laminin, nidogen and annexin. Proteomics. 2013; 13(15): 2312-2323.

[143] Guevel, L., Lavoie, J. R., Perez-Iratxeta, C., Rouger, K., Dubreil, L., Feron, M., Talon, S., Brand, M., and Megeney, L. A. Quantitative proteomic analysis of dystrophic dog muscle. J Proteome Res. 2011; 10(5): 2465-2478.

[144] Fairclough, R. J., Perkins, K. J., and Davies, K. E. Pharmacologically targeting the primary defect and downstream pathology in Duchenne muscular dystrophy. Curr Gene Ther. 2012; 12(3): 206-244.

[145] Benedetti, S., Hoshiya, H., and Tedesco, F. S. Repair or replace? Exploiting novel gene and cell therapy strategies for muscular dystrophies. FEBS J. 2013; 280(17): 4263-4280.

[146] Flanigan, K. M., Voit, T., Rosales, X. Q., Servais, L., Kraus, J. E., Wardell, C., Morgan, A., Dorricott, S., Nakielny, J., Quarcoo, N., Liefaard, L., Drury, T., Campion, G., and Wright, P. Pharmacokinetics and safety of single doses of drisapersen in non-ambulant subjects with Duchenne muscular dystrophy: Results of a double-blind randomized clinical trial. Neuromuscul Disord. 2014; 24(1): 16-24.

[147] Govoni, A., Magri, F., Brajkovic, S., Zanetta, C., Faravelli, I., Corti, S., Bresolin, N., and Comi, G. P. Ongoing therapeutic trials and outcome measures for Duchenne muscular dystrophy. Cell Mol Life Sci. 2013; 70(23): 4585-4602.

[148] Wells, G. D., Selvadurai, H., and Tein, I. Bioenergetic provision of energy for muscular activity. Paediatr Respir Rev. 2009; 10(3): 83-90.

[149] Russell, A. P., Foletta, V. C., Snow, R. J., and Wadley, G. D. Skeletal muscle mitochondria: A major player in exercise, 
health and disease. Biochim Biophys Acta. 2014; 1840(4): 1276-1284.

[150] Maughan, D. W., Henkin, J. A., and Vigoreaux, J. O. Concentrations of glycolytic enzymes and other cytosolic proteins in the diffusible fraction of a vertebrate muscle proteome. Mol Cell Proteomics. 2005; 4(10): 1541-1549.

[151] Ohlendieck, K. Proteomics of skeletal muscle glycolysis. Biochim Biophys Acta. 2010; 1804(11): 2089-2101.

152] Katsetos, C. D., Koutzaki, S., and Melvin, J. J. Mitochondrial dysfunction in neuromuscular disorders. Semin Pediatr Neurol. 2013; 20(3): 202-215.

[153] Kuznetsov, A. V., Winkler, K., Wiedemann, F. R., von Bossanyi, P., Dietzmann, K., and Kunz, W. S. Impaired mitochondrial oxidative phosphorylation in skeletal muscle of the dystrophin-deficient mdx mouse. Mol Cell Biochem. 1998; 183(2): 87-96.

[154] Percival, J. M., Siegel, M. P., Knowels, G., and Marcinek, D. J. Defects in mitochondrial localization and ATP synthesis in the mdx mouse model of Duchenne muscular dystrophy are not alleviated by PDE5 inhibition. Hum Mol Genet. 2013; 22(1): 153-167.

[155] Rakus, D., Mamczur, P., Gizak, A., Dus, D., and Dzugaj, A. Colocalization of muscle FBPase and muscle aldolase on both sides of the Z-line. Biochem Biophys Res Commun. 2003; 311(2): 294-299.

[156] Rakus, D., Pasek, M., Krotkiewski, H., and Dzugaj, A. Interaction between muscle aldolase and muscle fructose 1,6-bisphosphatase results in the substrate channeling. Biochemistry. 2004; 43(47): 14948-14957.

[157] Wang, J., and Pantopoulos, K. Regulation of cellular iron metabolism. Biochem J. 2011; 434(3): 365-381.

[158] Szőke, D., and Panteghini, M. Diagnostic value of transferrin. Clin Chim Acta. 2012; 413(15): 1184-1189.

[159] Allen, D. G., Gervasio, O. L., Yeung, E. W., and Whitehead, N. P. Calcium and the damage pathways in muscular dystrophy. Can J Physiol Pharmacol. 2010; 88(2): 83-91.

[160] Alderton, J. M., and Steinhardt, R. A. Calcium influx through calcium leak channels is responsible for the elevated levels of calcium-dependent proteolysis in dystrophic myotubes. J Biol Chem. 2000; 275(13): 9452-9460.

161] Mallouk, N., Jacquemond, V., and Allard, B. Elevated subsarcolemmal $\mathrm{Ca} 2+$ in $\mathrm{mdx}$ mouse skeletal muscle fibers detected with $\mathrm{Ca}^{2+}$-activated $\mathrm{K}^{+}$channels. Proc Natl Acad Sci USA. 2000; 97(9): 4950-4955.

[162] Dowling, P., Doran, P., and Ohlendieck, K. Drastic reduction of sarcalumenin in Dp427 (dystrophin of $427 \mathrm{kDa}$ )-deficient fibres indicates that abnormal calcium handling plays a key role in muscular dystrophy. Biochem J. 2004; 379(2): 479488.

[163] Culligan, K., Banville, N., Dowling, P., and Ohlendieck, $\mathrm{K}$. Drastic reduction of calsequestrin-like proteins and impaired calcium binding in dystrophic mdx muscle. J Appl Physiol. 2002; 92(2): 435-445.

[164] Krüger, J., Kunert-Keil, C., Bisping, F., and Brinkmeier, H. Transient receptor potential cation channels in normal and dystrophic mdx muscle. Neuromuscul Disord. 2008; 18(6): 501-513.

[165] McCarter, G. C., and Steinhardt, R. A. Increased activity of calcium leak channels caused by proteolysis near sarcolemmal ruptures. J Membr Biol. 2000; 176(2): 169-174.

[166] Alderton, J. M., and Steinhardt, R. A. How calcium influx through calcium leak channels is responsible for the elevated levels of calcium-dependent proteolysis in dystrophic myotubes. Trends Cardiovasc Med. 2000; 10(6): 268-272.
[167] Berchtold, M. W., Brinkmeier, H., and Müntener, M. Calcium ion in skeletal muscle: Its crucial role for muscle function, plasticity, and disease. Physiol Rev. 2000; 80(3): 1215-1265.

[168] Ohlendieck, K., and Campbell, K. P. Dystrophin-associated proteins are greatly reduced in skeletal muscle from $\mathrm{mdx}$ mice. J Cell Biol. 1991;115(6): 1685-1694.

[169] Ohlendieck, K., Matsumura, K., Ionasescu, V. V., Towbin, J. A., Bosch, E. P., Weinstein, S. L., Sernett, S. W., and Campbell, K. P. Duchenne muscular dystrophy: Deficiency of dystrophin-associated proteins in the sarcolemma. Neurology. 1993; 43(4): 795-800

[170] Holland, A., and Ohlendieck, K. Proteomic profiling of the dystrophin-deficient mdx heart, a phenocopy of dystrophinopathy-associated cardiomyopathy. BioMed Res Int. 2014; 214: 246195

[171] Carberry, S., and Ohlendieck, K. Gel electrophoresis-based proteomics of senescent tissues. Methods Mol Biol. 2013; 1048:229-246.

[172] Nicholl, I. D., and Quinlan, R. A. Chaperone activity of alpha-crystallins modulates intermediate filament assembly. EMBO J. 1994, 13, 945-953.

[173] Hauerslev, S., Sveen, M. L., Duno, M., Angelini, C., Vissing, J., and Krag, T. O. Calpain 3 is important for muscle regeneration: Evidence from patients with limb girdle muscular dystrophies. BMC Musculoskelet Disord. 2012; 13: 43.

[174] Schreiber, K. H., and Kennedy, B. K. When lamins go bad: Nuclear structure and disease. Cell. 2013; 152(6): 13651375.

[175] Kim, Y. E., Hipp, M. S., Bracher, A., Hayer-Hartl, M., and Hartl,F. U. Molecular chaperone functions in protein folding and proteostasis. Annu Rev Biochem. 2013; 82:323-355.

[176] Nishimura, R. N., and Sharp, F. R. Heat shock proteins and neuromuscular disease. Muscle Nerve. 2005; 32(6): 693709.

[177] Vos, M. J., Hageman, J., Carra, S., and Kampinga, H. H. Structural and functional diversities between members of the human HSPB, HSPH, HSPA, and DNAJ chaperone families. Biochemistry. 2008; 47(27): 7001-7011.

[178] Golenhofen, N., Perng, M. D., Quinlan, R. A., and Drenckhahn, D. Comparison of the small heat shock proteins alphaB-crystallin, MKBP, HSP25, HSP20, and cvHSP in heart and skeletal muscle. Histochem Cell Biol. 2004; 122(5): 415-425.

[179] Bornman, L., Polla, B. S., Lotz, B. P., and Gericke, G. S. Expression of heat-shock/stress proteins in Duchenne muscular dystrophy. Muscle Nerve. 1995; 18(1): 23-31.

[180] Paepe, B. D., Creus, K. K., Weis, J., and Bleecker, J. L. Heat shock protein families 70 and 90 in Duchenne muscular dystrophy and inflammatory myopathy: Balancing muscle protection and destruction. Neuromuscul Disord. 2012; 22(1): 26-33.

[181] Bornman, L., Rossouw, H., Gericke, G. S., and Polla, B. $\mathrm{S}$. Effects of iron deprivation on the pathology and stress protein expression in murine $\mathrm{X}$-linked muscular dystrophy. Biochem Pharmacol. 1998; 56(6): 751-757.

[182] Gehrig, S. M., van der Poel, C., Sayer, T. A., Schertzer, J. D., Henstridge, D. C., Church, J. E., Lamon, S., Russell, A. P., Davies, K. E., Febbraio, M. A., and Lynch, G. S. Hsp72 preserves muscle function and slows progression of severe muscular dystrophy. Nature. 2012; 484(7394): 394-398.

[183] Goonasekera, S. A. 1., Lam, C. K., Millay, D. P., Sargent, M. A., Hajjar, R. J., Kranias, E. G., and Molkentin, J. D. 
Mitigation of muscular dystrophy in mice by SERCA overexpression in skeletal muscle. J Clin Invest. 2011; 121(3): 1044-1052.

[184] Donoghue, P., Doran, P., and Ohlendieck, K. Role of chaperones in dystrophic and senescent skeletal muscle fibres. In: Haugen S, Meijer S, editors. Handbook of Nutritional Biochemistry. New York: Nova Science Publishers, 2010. pp. 195-224.

[185] Hauser, E., Höger, H., Bittner, R., Widhalm, K., Herkner, K., and Lubec, G. Oxyradical damage and mitochondrial enzyme activities in the mdx mouse. Neuropediatrics. 1995; 26(5): 260-262.

[186] Haycock, J. W., MacNeil, S., Jones, P., Harris, J. B., and Mantle, D. Oxidative damage to muscle protein in Duchenne muscular dystrophy. Neuroreport. 1996; 8(1): 357-361.

[187] Renjini, R., Gayathri, N., Nalini, A., and Srinivas Bharath, M. M. Oxidative damage in muscular dystrophy correlates with the severity of the pathology: Role of glutathione metabolism. Neurochem Res. 2012; 37(4): 885-898.

[188] Tidball, J. G., and Wehling-Henricks, M. The role of free radicals in the pathophysiology of muscular dystrophy. J Appl Physiol. 2007; 102(4): 1677-1686.

[189] Board, P. G., and Menon, D. Glutathione transferases, regulators of cellular metabolism and physiology. Biochim Biophys Acta. 2013; 1830(5): 3267-3288.

[190] Selsby, J. T. Increased catalase expression improves muscle function in mdx mice. Exp Physiol. 2011; 96(2): 194-202.

[191] McDonald, C. M., Henricson, E. K., Abresch, R. T., Florence, J. M., Eagle, M., Gappmaier, E., and Glanzman, A. M.; PTC124-GD-007-DMD Study Group, Spiegel, R., Barth, J., Elfring, G., Reha, A., and Peltz, S. The 6-minute walk test and other endpoints in Duchenne muscular dystrophy: Longitudinal natural history observations over 48 weeks from a multicenter study. Muscle Nerve. 2013; 48(3): 343-356.

[192] McDonald, C. M., Henricson, E. K., Abresch, R. T., Florence, J., Eagle, M., Gappmaier, E., Glanzman, A. M.; PTC124-GD-007-DMD Study Group, Spiegel, R., Barth, J., Elfring, G., Reha, A., and Peltz, S. W. The 6-minute walk test and other clinical endpoints in duchenne muscular dystrophy: Reliability, concurrent validity, and minimal clinically important differences from a multicenter study. Muscle Nerve. 2013; 48(3): 357-368.

[193] de Lattre, C., Payan, C., Vuillerot, C., Rippert, P., de Castro, D., Bérard, C., Poirot, I.; MFM-20 Study Group. Motor function measure: Validation of a short form for young children with neuromuscular diseases. Arch Phys Med Rehabil. 2013; 94(11): 2218-2226.

[194] Servais, L., Deconinck, N., Moraux, A., Benali, M., Canal, A., Van Parys, F., Vereecke, W., Wittevrongel, S., Mayer, M., Desguerre, I., Maincent, K., Themar-Noel, C., QuijanoRoy, S., Serari, N., Voit, T., and Hogrel, J. Y. Innovative methods to assess upper limb strength and function in nonambulant Duchenne patients. Neuromuscul Disord. 2013; 23(2): 139-148.

[195] Finanger, E. L., Russman, B., Forbes, S. C., Rooney, W. D., Walter, G. A., and Vandenborne, K. Use of skeletal muscle MRI in diagnosis and monitoring disease progression in Duchenne muscular dystrophy. Phys Med Rehabil Clin N Am. 2012; 23(1): 1-10.

[196] Hollingsworth, K. G., Garrood, P., Eagle, M., Bushby, K., and Straub, V. Magnetic resonance imaging in Duchenne muscular dystrophy: Longitudinal assessment of natural history over 18 months. Muscle Nerve. 2013; 48(4): 586-588.
[197] Fischmann, A., Hafner, P., Gloor, M., Schmid, M., Klein, A., Pohlman, U., Waltz, T., Gonzalez, R., Haas, T., Bieri, O., and Fischer, D. Quantitative MRI and loss of free ambulation in Duchenne muscular dystrophy. J Neurol. 2013; 260(4): 969-974.

[198] Forbes, S. C., Walter, G. A., Rooney, W. D., Wang, D. J., DeVos, S., Pollaro, J., Triplett, W., Lott, D. J., Willcocks, R. J., Senesac, C., Daniels, M. J., Byrne, B. J., Russman, B., Finkel, R. S., Meyer, J. S., Sweeney, H. L., and Vandenborne, K. Skeletal muscles of ambulant children with Duchenne muscular dystrophy: Validation of multicenter study of evaluation with MR imaging and MR spectroscopy. Radiology. 2013; 269(1): 198-207.

[199] Willcocks, R. J., Arpan, I. A., Forbes, S. C., Lott, D. J., Senesac, C. R., Senesac, E., Deol, J., Triplett, W. T., Baligand, C., Daniels, M. J., Sweeney, H. L., Walter, G. A., and Vandenborne, K. Longitudinal measurements of MRI-T2 in boys with Duchenne muscular dystrophy: Effects of age and disease progression. Neuromuscul Disord. 2014. [in press].

[200] Kinali, M., Arechavala-Gomeza, V., Cirak, S., Glover, A., Guglieri, M., Feng, L., Hollingsworth, K. G., Hunt, D., Jungbluth, H., Roper, H. P., Quinlivan, R. M., Gosalakkal, J. A., Jayawant, S., Nadeau, A., Hughes-Carre, L., Manzur, A. Y., Mercuri, E., Morgan, J. E., Straub, V., Bushby, K., Sewry, C., Rutherford, M., and Muntoni, F. Muscle histology vs MRI in Duchenne muscular dystrophy. Neurology. 2011; 76(4): 346-353.

[201] Proud, C. M. 50 years ago in the Journal of Pediatrics: The use of serum creatine phosphokinase and other serum enzymes in the diagnosis of progressive muscular dystrophy. J Pediatr. 2013; 163(6): 1656.

[202] Swaiman, K. F., and Sandler, B. The use of serum creatine phosphokinase and other serum enzymes in the diagnosis of progressive muscular dystrophy. J Pediatr. 1963; 63: 11161119.

[203] Pearce, J. M., Pennington, R. J., and Walton, J. N. Serum enzyme studies in muscle disease. iii. serum creatine kinase activity in relatives of patients with the duchenne type of muscular dystrophy. J Neurol Neurosurg Psychiatry. 1964; 27: 181-185.

[204] Zellweger, H., and Antonik, A. Newborn screening for Duchenne muscular dystrophy. Pediatrics. 1975; 55(1): 3034.

[205] Drummond, L. M. Creatine phosphokinase levels in the newborn and their use in screening for Duchenne muscular dystrophy. Arch Dis Child. 1979; 54(5): 362-366.

[206] Percy, M. E., Andrews, D. F., and Thompson, M. W. Duchenne muscular dystrophy carrier detection using logistic discrimination: Serum creatine kinase, hemopexin, pyruvate kinase, and lactate dehydrogenase in combination. Am J Med Genet. 1982; 13(1): 27-38.

[207] Yasmineh, W. G., Ibrahim, G. A., Abbasnezhad, M., and Awad, E. A. Isoenzyme distribution of creatine kinase and lactate dehydrogenase in serum and skeletal muscle in Duchenne muscular dystrophy, collagen disease, and other muscular disorders. Clin Chem. 1978; 24(11): 1985-1989.

[208] Zatz, M., Rapaport, D., Vainzof, M., Passos-Bueno, M. R., Bortolini, E. R., Pavanello Rde, C., and Peres, C. A. Serum creatine-kinase $(\mathrm{CK})$ and pyruvate-kinase $(\mathrm{PK})$ activities in Duchenne (DMD) as compared with Becker (BMD) muscular dystrophy. J Neurol Sci. 1991; 102(2): 190-196.

[209] Carter, N. D., Heath, R., Jeffery, S., Jackson, M. J., Newham, D. J., and Edwards, R. H. Carbonic anhydrase III in Duchenne muscular dystrophy. Clin Chim Acta. 1983; 133(2): 201-208. 
[210] Mokuno, K., Riku, S., Matsuoka, Y., Sobue, I., and Kato, K. Serum carbonic anhydrase III in progressive muscular dystrophy. J Neurol Sci. 1985; 67(2): 223-228.

[211] Väänänen, H. K., Takala, T. E., Tolonen, U., Vuori, 31 J., and Myllylä, V. V. Muscle-specific carbonic anhydrase III is a more sensitive marker of muscle damage than creatine kinase in neuromuscular disorders. Arch Neurol. 1988; 45(11): 1254-1256.

[212] Ohta, M., Itagaki, Y., Itoh, N., Hayashi, K., Nishitani, H., and Ohta, K. Carbonic anhydrase III in serum in muscular dystrophy and other neurological disorders: Relationship with creatine kinase. Clin Chem. 1991; 37(1): 36-39.

[213] Soltan, H. C., and Blanchaer, M. C. Activity of serum aldolase and lactic dehydrogenase in patients affected with Duchenne muscular dystrophy and in their immediate relatives. J Pediatr. 1959; 54(1) :27-33.

[214] Hamada, M., Okuda, H., Oka, K., Watanabe, T., Ueda, K., Nojima, M., Kuby, S. A., Manship, M., Tyler, F. H., and Ziter, F. A. An aberrant adenylate kinase isoenzyme from the serum of patients with Duchenne muscular dystrophy. Biochim Biophys Acta. 1981; 660(2): 227-237.

[215] Hamada, M., Sumida, M., Kurokawa, Y., SunayashikiKusuzaki, K., Okuda, H., Watanabe, T., and Kuby, S. A. Studies on the adenylate kinase isozymes from the serum and erythrocyte of normal and Duchenne dystrophic patients. Isolation, physicochemical properties, and several comparisons with the Duchenne dystrophic aberrant enzyme. J Biol Chem. 1985; 260(21): 11595-11602.

[216] Fröhlich, T., Reitter, B., Scheffner, D., Schirmer, R. H., and Untucht-Grau, R. Muscle adenylate kinase in Duchenne muscular dystrophy. Biochim Biophys Acta. 1986; 883(3): 598-603.

[217] Seay, A. R., Ziter, F. A., Wu, L. H., and Wu, J. T. Serum creatine phosphokinase and pyruvate kinase in neuromuscular disorders and Duchenne dystrophy carriers. Neurology. 1978; 28(10): 1047-1050

[218] Percy, M. E., Chang, L. S., Murphy, E. G., Oss, I., VerellenDumoulin, C., and Thompson, M. W. Serum creatine kinase and pyruvate kinase in Duchenne muscular dystrophy carrier detection. Muscle Nerve. 1979; 2(5): 329-339.

[219] Carter, N. D., Heath, R., Jeffery, S., and Rodeck, C. Fetal plasma carbonic anhydrase III in Duchenne dystrophy. Lancet. 1982; 1(8262): 39-40.

[220] Heath, R., Carter, N. D., Jeffery, S., Edwards, R. J., Watts, D. C., Watts, R. L., and Rodeck, C. Fetal plasma carbonic anhydrase III in prenatal diagnosis of Duchenne muscular dystrophy. Am J Med Genet. 1985; 20(1): 115-122.

[221] Mendell, J. R., Shilling, C., Leslie, N. D., Flanigan, K. M., al-Dahhak, R., Gastier-Foster, J., Kneile, K., Dunn, D. M., Duval, B., Aoyagi, A., Hamil, C., Mahmoud, M., Roush, K., Bird, L., Rankin, C., Lilly, H., Street, N., Chandrasekar, R., and Weiss, R. B. Evidence-based path to newborn screening for Duchenne muscular dystrophy. Ann Neurol. 2012; 71(3): 304-313.

[222] Richterich, R., Rosin, S., Aebi, U., and Rossi, E. Progressive Muscular Dystrophy. V. The Identification of the Carrier State in the Duchenne Type by Serum Creatine Kinase Determination. Am J Hum Genet. 1963; 15(2): 133-154.

[223] Zatz, M., and Otto, P. A. The use of concomitant serum pyruvate-kinase $(\mathrm{PK})$ and creatine-phosphokinase $(\mathrm{CPK})$ for carrier detection in Duchenne's muscular dystrophy through discriminant analysis. J Neurol Sci. 1980; 47(3): 411-417.

[224] Hyser, C. L., Griggs, R. C., Mendell, J. R., Polakowska, R., Quirk, S., Brooke, M. H., Fenichel, G. M., and Doherty,
R. A. Use of serum creatine kinase, pyruvate kinase, and genetic linkage for carrier detection in Duchenne and Becker dystrophy. Neurology. 1987; 37(1): 4-10.

[225] Zatz, M., and Otto, P. A. Evaluation of carrier detection rates for Duchenne and Becker muscular dystrophies using serum creatine-kinase (CK) and pyruvate-kinase (PK) through discriminant analysis. Am J Med Genet. 1986; 25(2): 219-230.

[226] Heath, R., Carter, N. D., Jeffery, S., Edwards, R. J., Watts, D. C., and Watts, R. L. Evaluation of carrier detection of Duchenne muscular dystrophy using carbonic anhydrase III and creatine kinase. Am J Med Genet. 1985; 21(2): 291-296.

[227] Percy, M. E., Pichora, G. A., Chang, L. S., Manchester, K. E., and Andrews, D. F. Serum myoglobin in Duchenne muscular dystrophy carrier detection: A comparison with creatine kinase and hemopexin using logistic discrimination. Am J Med Genet. 1984; 18(2): 279-287.

[228] Tyan, Y. C., Guo, H. R., Liu, C. Y., and Liao, P. C. Proteomic profiling of human urinary proteome using nano-high performance liquid chromatography/electrospray ionization tandem mass spectrometry. Anal Chim Acta. 2006; 579(2): 158-176.

[229] Rodríguez-Suárez, E., Siwy, J., Zürbig, P., Mischak, H. Urine as a source for clinical proteome analysis: From discovery to clinical application. Biochim Biophys Acta. 2014; 1844(5): 884-898.

[230] Al Kawas, S., Rahim, Z. H., and Ferguson, D. B. Potential uses of human salivary protein and peptide analysis in the diagnosis of disease. Arch Oral Biol. 2012; 57(1): 1-9.

[231] Zhang, A., Sun, H., Wang, P., and Wang, X. Salivary proteomics in biomedical research. Clin Chim Acta. 2013; 415: 261-265.

[232] Froehlich, J. W., Vaezzadeh, A. R., Kirchner, M., Briscoe, A. C., Hofmann, O., Hide, W., Steen, H., and Lee, R. S. An in-depth comparison of the male pediatric and adult urinary proteomes. Biochim Biophys Acta. 2014; 1844(5): 10441050 .

[233] Sampson, D. L., Broadbent, J. A., Parker, A. W., Upton, Z., and Parker, T. J. Urinary biomarkers of physical activity: Candidates and clinical utility. Expert Rev Proteomics. 2014; 11(1): 91-106.

[234] Skipworth, R. J., Stewart, G. D., Bhana, M., Christie, J., Sturgeon, C. M., Guttridge, D. C., Cronshaw, A. D., Fearon, K. C., and Ross, J. A. Mass spectrometric detection of candidate protein biomarkers of cancer cachexia in human urine. Int J Oncol. 2010; 36(4): 973-982.

[235] Veenstra, T. D., Conrads, T. P., Hood, B. L., Avellino, A. M., Ellenbogen, R. G., and Morrison, R. S. Biomarkers: Mining the biofluid proteome. Mol Cell Proteomics. 2005; 4(4): 409-418

[236] Savino, R., Paduano, S., Preianò, M., and Terracciano, R. The proteomics big challenge for biomarkers and new drugtargets discovery. Int J Mol Sci. 2012; 13(11): 13926-13948.

[237] Stastna, M., and Van Eyk, J. E. Secreted proteins as a fundamental source for biomarker discovery. Proteomics. 2012; 12(4): 722-735.

[238] Rai, A. J., Gelfand, C. A., Haywood, B. C., Warunek, D. J., Yi, J., Schuchard, M. D., Mehigh, R. J., Cockrill, S. L., Scott, G. B., Tammen, H., Schulz-Knappe, P., Speicher, D. W., Vitzthum, F., Haab, B. B., Siest, G., and Chan, D. W. HUPO Plasma Proteome Project specimen collection and handling: Towards the standardization of parameters for plasma proteome samples. Proteomics. 2005; 5(13): 3262-3277.

[239] Omenn, G. S., States, D. J., Adamski, M., Blackwell, T. W., Menon, R., Hermjakob, H., Apweiler, R., Haab, B. B., Simpson, R. J., Eddes, J. S., Kapp, E. A., Moritz, R. L., Chan, D. 
W., Rai, A. J., Admon, A., Aebersold, R., Eng, J., Hancock, W. S., Hefta, S. A., Meyer, H., Paik, Y. K., Yoo, J. S., Ping, P., Pounds, J., Adkins, J., Qian, X., Wang, R., Wasinger, V., Wu, C. Y., Zhao, X., Zeng, R., Archakov. A., Tsugita, A., Beer, I., Pandey, A., Pisano, M., Andrews, P., Tammen, H., Speicher, D. W., Hanash, S. M. Overview of the HUPO Plasma Proteome Project: Results from the pilot phase with 35 collaborating laboratories and multiple analytical groups, generating a core dataset of 3020 proteins and a publiclyavailable database. Proteomics. 2005; 5(13): 3226-3245.

[240] Alsaif, M., Guest, P. C., Schwarz, E., Reif, A., KittelSchneider, S., Spain, M., Rahmoune, H., and Bahn, S. Analysis of serum and plasma identifies differences in molecular coverage, measurement variability, and candidate biomarker selection. Proteomics Clin Appl. 2012; 6(5): 297-303.

[241] Anderson, N. L., and Anderson, N. G. The human plasma proteome: History, character, and diagnostic prospects. Mol Cell Proteomics. 2002; 1(11): 845-867.

[242] von Moers, A., Danne, T., Möller, P., and Scheffner, D. Serum levels of carboxyterminal propeptide of type I procollagen, aminoterminal propeptide of type III procollagen and laminin P1 in Duchenne muscular dystrophy. Acta Paediatr. 1997; 86(4): 377-380.

[243] Sun, G., Haginoya, K., Chiba, Y., Uematsu, M., HinoFukuyo, N., Tanaka, S., Onuma, A., Iinuma, K., Tsuchiya, S. Elevated plasma levels of tissue inhibitors of metalloproteinase- 1 and their overexpression in muscle in human and mouse muscular dystrophy. J Neurol Sci. 2010; 297(2): 19-28.

[244] D'Amore, P. A., Brown, R. H., Jr., Ku, P. T., Hoffman, E. P., Watanabe, H., Arahata, K., Ishihara, T., and Folkman, J. Elevated basic fibroblast growth factor in the serum of patients with Duchenne muscular dystrophy. Ann Neurol. 1994; 35(3): 362-365.

[245] Bernasconi, P., Torchiana, E., Confalonieri, P., Brugnoni, R., Barresi, R., Mora, M., Cornelio, F., Morandi, L., and Mantegazza, R. Expression of transforming growth factorbeta 1 in dystrophic patient muscles correlates with fibrosis. Pathogenetic role of a fibrogenic cytokine. J Clin Invest. 1995; 96(2): 1137-1144.

[246] Ishitobi, M., Haginoya, K., Zhao, Y., Ohnuma, A., Minato, J., Yanagisawa, T., Tanabu, M., Kikuchi, M., and Iinuma, K. Elevated plasma levels of transforming growth factor beta1 in patients with muscular dystrophy. Neuroreport. 2000; 11(18): 4033-4035
[247] Pedersen, B. K. Muscle as a secretory organ. Compr Physiol. 2013; 3(3): 1337-1362.

[248] Weigert, C., Lehmann, R., Hartwig, S., and Lehr, S. The secretome of the working human skeletal muscle-A promising opportunity to combat the metabolic disaster? Proteomics Clin Appl. 2014; 8(2): 5-18.

[249] Nilsson, M. I., Nissar, A. A., Al-Sajee, D., Tarnopolsky, M. A., Parise, G., Lach, B., Fürst, D. O., van der Ven, P. F., Kley, R. A., and Hawke, T. J. Xin is a marker of skeletal muscle damage severity in myopathies. Am J Pathol. 2013; 183(6): 1703-1709.

[250] Klymiuk, N., Blutke, A., Graf, A., Krause, S., Burkhardt, K., Wuensch, A., Krebs, S., Kessler, B., Zakhartchenko, V., Kurome, M., Kemter, E., Nagashima, H., Schoser, B., Herbach, N., Blum, H., Wanke, R., Aartsma-Rus, A., Thirion, C., Lochmüller, H., Walter, M. C., and Wolf, E. Dystrophin-deficient pigs provide new insights into the hierarchy of physiological derangements of dystrophic muscle. Hum Mol Genet. 2013; 22(21): 4368-4382.

[251] Mizuno, H., Nakamura, A., Aoki, Y., Ito, N., Kishi, S., Yamamoto, K., Sekiguchi, M., Takeda, S., and Hashido, K. Identification of muscle-specific microRNAs in serum of muscular dystrophy animal models: Promising novel bloodbased markers for muscular dystrophy. PLoS One. 2011; 6(3): e18388.

[252] Cacchiarelli, D., Legnini, I., Martone, J., Cazzella, V., D'Amico, A., Bertini, E., and Bozzoni, I. miRNAs as serum biomarkers for Duchenne muscular dystrophy. EMBO Mol Med. 2011; 3(5): 258-65.

[253] Roberts, T. C., Blomberg, K. E., McClorey, G., El Andaloussi, S., Godfrey, C., Betts, C., Coursindel, T., Gait, M. J., Smith, C. I., and Wood, M. J. Expression analysis in multiple muscle groups and serum reveals complexity in the microRNA transcriptome of the mdx mouse with implications for therapy. Mol Ther Nucleic Acids. 2012; 1: e39.

[254] Zaharieva, I. T., Calissano, M., Scoto, M., Preston, M., Cirak, S., Feng, L., Collins, J., Kole, R., Guglieri, M., Straub, V., Bushby, K., Ferlini, A., Morgan, J. E., and Muntoni, F. Dystromirs as serum biomarkers for monitoring the disease severity in Duchenne muscular Dystrophy. PLoS One. 2013; 8(11): e80263.

[255] Hu, J., Kong, M., Ye, Y., Hong, S., Cheng, L., and Jiang, L. Serum miR-206 and other muscle-specific microRNAs as non-invasive biomarkers for Duchenne muscular dystrophy. J Neurochem. 2014; 129(5): 877-883. 